\title{
The mechanism of plant gall induction by insects: revealing clues, facts, and consequences in a cross-kingdom complex interaction
}

\author{
Omar Gätjens-Boniche \\ Laboratorio de Biología Molecular, Escuela de Ciencias Naturales y Exactas, Campus Tecnológico Local San Carlos, \\ Instituto Tecnológico de Costa Rica. Santa Clara, San Carlos, Alajuela, Costa Rica; ogatjens@itcr.ac.cr, \\ ogatjensboniche@gmail.com
}

\section{Received 07-XI-2018. Corrected 28-V-2019. Accepted 23-IX-2019.}

\begin{abstract}
Galls are defined as modifications of the normal developmental design of plants, produced by a specific reaction to the presence and activity of a foreign organism. Although different organisms have the ability to induce galls in plants, insect-induced galls are the most elaborate and diverse. Some hypotheses have been proposed to explain the induction mechanism of plant galls by insects. The most general hypothesis suggests that gall formation is triggered by the action of chemical substances secreted by the gall inducer, including plant growth regulators such as auxins, cytokinins, indole-3-acetic acid (IAA), and other types of compounds. However, the mode of action of these chemical substances and the general mechanism by which the insect could control and manipulate plant development and physiology is still not known. Moreover, resulting from the complexity of the induction process and development of insect galls, the chemical hypothesis is very unlikely a complete explanation of the mechanism of induction and morphogenesis of these structures. Previous and new highlights of insect gall systems with emphasis on the induction process were analyzed on the basis of the author's integrated point of view to propose a different perspective of gall induction, which is provided in this article. Due to the extraordinary diversity of shapes, colors, and complex structures present in insect galls, they are useful models for studying how form and structure are determined at the molecular level in plant systems. Furthermore, plant galls constitute an important source of material for the study and exploration of new chemical substances of interest to humans, due to their physiological and adaptive characteristics. Considering the finely tuned control of morphogenesis, structural complexity, and biochemical regulation of plant galls induced by insects, it is proposed that an induction mechanism mediated by the insertion of exogenous genetic elements into the genome of plant gall cells could be involved in the formation of this kind of structure through an endosymbiotic bacterium.
\end{abstract}

Key words: insect galls, inductor insect, induction mechanism, plant morphogenesis, effectors.

Gätjens-Boniche, O. (2019). The mechanism of plant gall induction by insects: revealing clues, facts, and consequences in a cross-kingdom complex interaction. Revista de Biología Tropical, 67(6), 1359-1382.

The term plant gall has been applied to different systems, and although there is no consensus about the definition of the term, the same has been used as a generalized expression more than a precise scientific term or concept (Williams, 1994). Nonetheless, in general terms, galls could be defined as deviations in the normal plant development pattern, produced by a specific reaction to the presence and activity of a foreign organism (Shorthouse \& Rohfritsch, 1992; Inbar et al., 2009; Huang et al., 2015). Gall-inducing insects, also called gall inducers, gall makers, or simply gallers, live within the plant tissue, which supplies food, low levels of potentially harmful chemical substances, protection against unfavorable 
environmental factors (Nogueira, Costa, Silva, \& Isaias, 2018), and shelter against natural enemies (Mani, 1992; Ananthakrishnan, 1998; Raman, Schaefer, \& Withers, 2005; Tooker \& De Moraes, 2008; Tooker, Rohr, Abrahamson, \& De Moraes, 2008; Huang et al., 2015; Isaias et al., 2018).

The meaning of the adaptive value of galls and the kind of biological interaction existing between gall-inducing insects and their host plants is the subject of a continuous debate among the different groups of researchers that work in the field (Nyman \& Julkunen 2000; Stone \& Schönrogge, 2003). Some groups established that galls originated as a mechanism of defense developed by insects against attack by their natural enemies. Moreover, the main function of the gall is to give shelter and food to the larvae of the galling insect; however, this and other related ideas are still the target of extensive debate (Ananthakrishnan, 1998; Stone \& Cook 1998; Price, Waring \& Fernández, 1986; Stone \& Schönrogge, 2003; Tooker et al., 2008; Giron, Huguet, Stone, \& Body, 2016). Different lines of thought relate galls with processes of pathogenesis, symbiosis, and defense mechanisms in plants (Hartnett \& Abrahamson, 1979; Price et al., 1986). Regardless of the type of specific interaction between gall-inducing insects and their host plants, natural selection consequently operates on the insect to stimulate the development of protective and/or nutritive tissues in the plant; on the other hand, in the plant, natural selection acts to resist the stimulus generated by the insect (Ananthakrishnan, 1998).

Hymenoptera and Diptera are two orders with a particularly large number of gall inducers, but great diversity can also be found in galls formed by thrips, aphids, and insects from other orders (Ananthakrishnan, 1998; Hanson \& Gómez-Laurito, 2005). A large number and diversity of plant gall morphotypes and inducing insects have been reported worldwide (Espírito-Santo \& Fernandes, 2007). New species of inducing insects are periodically described, while other studies on the abundance and diversity of gall morphotypes, as well as their corresponding inducers, has helped to broaden the existing knowledge in this field (Shorthouse \& Rohfritsch, 1992; Williams, 1994; Ronquist \& Liljeblad, 2001; Hanson \& Gómez-Laurito, 2005; Dalbem \& Mendonça, 2006; Güçlü, Hayat, Shorthouse, \& Göksel, 2008; Coelho et al., 2009; Maia, Fernandes, Magalhãcs, \& Santos, 2010a; Maia, Fleury, Soares, \& Isaias, 2010b; Medianero, Paniagua, \& Castaño-Meneses, 2010; Maia \& Oliveira, 2010; Santos, Almeida-Cortez \& Fernandes, 2011; Sano, Havil, \& Ozaki, 2011; Maia, 2014; Santos de Araújo, 2017; Martins dos Santos, Pereira Lima, Souza Suares, \& Calado, 2018).

Besides insects, plant galls are also induced by a great variety of organisms such as bacteria, fungi, nematodes, and mites (Leitch, 1994; Williams, 1994; Ananthakrishnan, 1998, Raman, 2011). Galls induced by insects are distinct from those induced by fungi and bacteria in their form, organization, and complexity. More complex and diverse galls are induced by insects such as those of the Cynipidae and Cecidiomyiidae families, which show extreme examples of radial symmetry, belonging to the orders Hymenoptera and Diptera, respectively (Raman, Cruz, Muniappan, \& Reddy, 2007; Sinnott, 1960; Raman, 2011). A general scheme for the structural complexity of plant galls and the taxonomic groups of their inducers is proposed by the author from the reviewed literature (Fig. 1) (Rohfritsch \& Shorthouse, 1982; Mani, 1992; Davey, Curtis, Gartland, \& Power, 1994; Gómez \& Kisimova-Horovitz, 1997; Williams, 1994; Valentine, 2003; Sá et al., 2009; Raman 2011; Álvarez, Molist, González-Sierra, Martínez, \& Nieto-Nafría, 2014; Formiga, Silveira, Fernandes, \& Isaias, 2015; Muñoz-Viveros et al., 2014; Guimarães, Neufeld, Santiago-Fernandes, \& Viera, 2015; Hernández-Soto et al., 2015; Suzuki, Moriguchi, \& Yamamoto, 2015; Mellah, Enhassaïni, \& Álvarez, 2016; Oliveira et al., 2016; Richardson, Body, Warmund, Schultz, \& Appel, 2016; Ferreira, Álvarez, Avritzer, \& Isaias, 2017; Palomares-Rius, Escobar, Cabrera, Vovlas, \& Castillo, 2017; Cotrim Costa, Gonçalves da Silva Carneiro, Santos Silva, \& Isaias, 2018; 
Nogueira, Costa, Silva, \& Isaias, 2018); however, a consensus on this approach does not exist, and substantial variation can be observed within each group.

The fact that different groups of insects possess the capacity to form galls in a wide variety of plants has motivated a great number of investigations attempting to elucidate the mechanism of induction of this type of structure. Nevertheless, considering the importance of galls as models for understanding a series of fundamental processes in the development of plants, the induction mechanisms and the evolutionary context of this type of structure is still poorly understood (Stone \& Schönrogge, 2003, Raman, 2011; Oates, Denby, Myburg, Slippers, \& Naidoo, 2016).

The aim of this paper is to provide an updated general description of plant galls induced by insects, focused on the induction process as well as how, according to an integrated interpretation by the author, the associated characteristics of these structures and the biological processes they regulate could be the basis for an alternative induction hypothesis mediated by the insertion of exogenous genetic elements into the plant gall cells through some endosymbiotic bacteria originating from the insect.

\section{Plant gall development and diversity of plant gall-inducing insects}

The association between galls and their inducing organisms has likely been recognized since the study of these systems began (Mani, 1992). However, it was not until the $17^{\text {th }}$ century that Malpighi described, in the Western World, that the growth and development of these structures was correlated to the activity of feeding, oviposition, and particular nutritional requirements of the inducing insect (Fagan, 1918; Hough, 1953).

Gall morphogenesis is a complex phenomenon, which involves reorientation of the

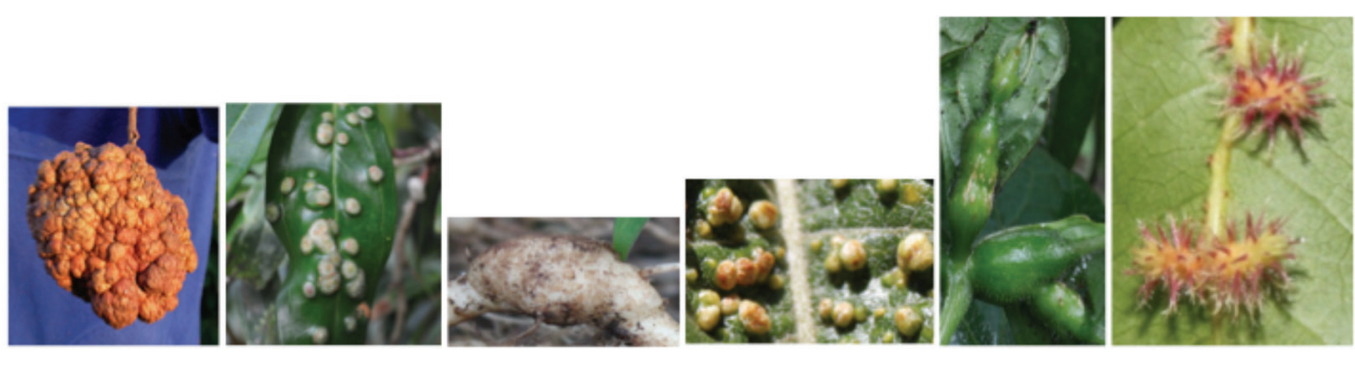

Bacteria Fungus Nematodes Insects

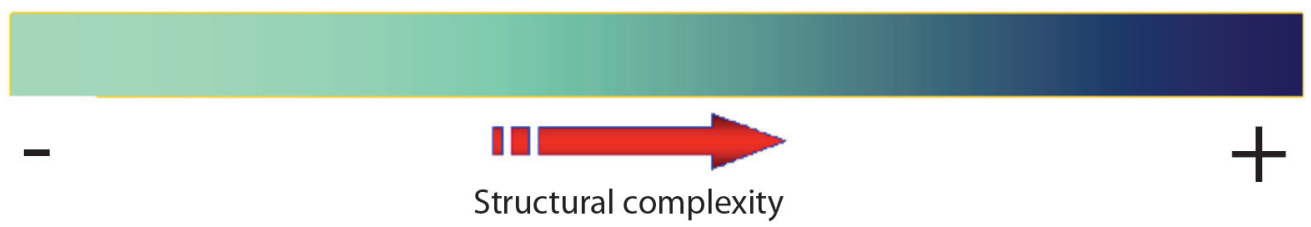

Fig. 1. Proposed general scheme for the structural complexity of plant galls and the taxonomic groups of gall inducers. Images show some examples of galls. Bacteria crown gall found on Pittosporum sp. (Pittosporaceae), induced by Agrobacterium tumefaciens. Fungus gall on Satyria warszewiczii (Ericaceae), induced by Exobasidium emeritense. Nematode gall induced by Meloidogyne incognita on Solanum lycopersicum (tomato, Solanaceae). Mite gall induced on Acnistus arboresens (Solanaceae). Insect gall induced on Cissus fuliginea (Vitaceae) by an unknown diptera Cecidomyiidae and on Hirtella racemosa (Chrysobalanaceae) by an unknown diptera Cecidomyiidae. Taxonomic identification of host plants of insect galls was performed by Roberto Espinoza, and inductor insects were identified by Paul Hanson. Photo credit: taken from Patrick Roper (bacteria crown gall), Omar Gätjens-Boniche (fungus gall, nematode gall, mite gall and insect galls). 
plant's development by the inducing insect (Ananthakrishnan, 1998; Raman, 2011; Oates, Külheim, Myburg, Slippers, \& Naidoo, 2015; Agudelo et al., 2018). The degree to which the insect manipulates the plant's growth to form the gall varies considerably and involves changes ranging from the induction of cell proliferation (Agudelo et al., 2018) to the formation of a complex structure that the plant does not produce under normal conditions. Just like normal plant organs and structures, galls induced by insects present anatomic and histologic characteristics of their own, which vary greatly in their diversity and degree of complexity (Fig. 2) (Nyman \& Julkunen, 2000; Mani, 1992; Ananthakrishnan, 1998; Stone \& Schönrogge, 2003; Oliveira \& Isaias, 2010; Raman, 2011; Oliveira, Carneiro, Magalhães, \& Isaias, 2011; Oliveira et al., 2016). Tissues near the inducing insect show cytological and morphological changes that benefit its feeding process and development. This tissue, also known as "nutritive tissue", commonly presents high concentrations of sugar (Nogueira et al., 2018), lipids, proteins, nitrogen, and other nutrients that provide a continuous source of food for the insect and show intense phosphatase activity (Miles, 1968; Rohfritsch \& Shorthouse, 1982; Shorthouse \& Rohfritsch, 1992; Raman, 2011, Oliveira \& Isaias, 2010; Oliveira et al., 2011; Nabity, Haus, Berenbaum, \& Delucia, 2013; Huang et al., 2015; Oates et al., 2016; Ferreira et al., 2017; Isaias et al., 2018). Typical nutritive cells show a dense cytoplasm with abundant cell organelles, fragmented vacuoles, a hypertrophied nucleus and nucleolus, and dedifferentiated plastids clustered around the nucleus, as well as chloroplasts modified
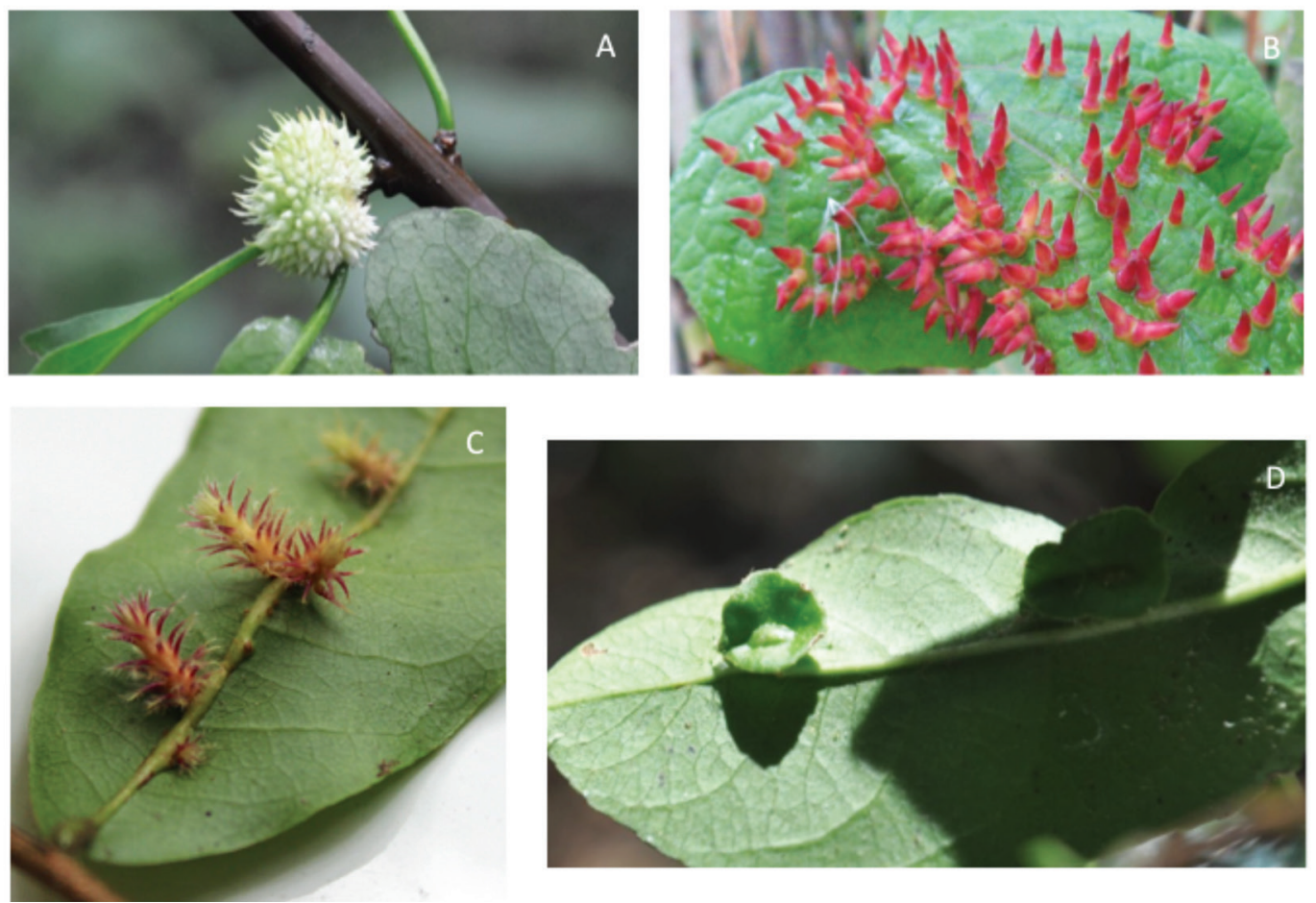

Fig. 2. Some plant galls from Costa Rican flora. A) Gall induced on Pisonia macranthocarpa (Nyctaginaceae) by an unidentified insect species (Diptera, Cecidomyiidae). B) Gall induced on Vitis tiliifolia (Vitaceae) by an unidentified insect species (Diptera, Cecidomyiidae). C) Gall induced on Hirtella racemosa (Chrysobalanaceae) by an unidentified insect species (Diptera, Cecidomyiidae). D) Gall induced on Semialarium mexicanum (Hippocrateaceae) by an unknown inducer. Taxonomic identification of the host plants was carried out by Roberto Espinoza, and the inductor insects were identified by Paul Hanson. Photo credit: Omar Gätjens-Boniche (A, C, and D) and Gregorio Dauphin (B). 
to varying degrees and modified cell walls (Shorthouse \& Rohfritsch, 1992; Raman, 2011; Carneiro \& Isaias, 2015). Ferreira et al. (2017) compared six gall systems with different levels of structural complexity (aphids, mites, and Nematoda), using histometric and histochemical analyses. Based on the types of storage tissue, the authors proposed a classification of three types of storage tissues: typical nutritive tissues (TNT), common storage tissues (CST), and nutritive-like tissues (NLT). TNT and NLT present cells with a dense cytoplasm and a large nucleus; TNT serve as a direct food source for gall inducers. CST have vacuolated cells, and may store starch and other types of energy-rich molecules, as do the cells of NLT. Likewise, several studies have demonstrated that insects generally feed on a reduced area of the gall (Nyman \& Julkunen, 2000).

The inducing insect can modify the expression of genes within restricted areas of the host plant, thereby producing new developmental events in the tissues under its influence. Gall morphogenesis occurs in a relatively short time; however, this fact apparently does not influence the complexity observed in such morphological entities (Ananthakrishnan, 1998, Nabity et al., 2013; Oates et al., 2015).

In many kinds of abnormal growth or deviation from normal organismal development, there are alterations in the mechanisms that regulate cell proliferation and differentiation. Within this context, "crown galls" induced by the genus Agrobacterium are an example of structures formed due to the proliferation of cells with a low level of differentiation; hence, they are considered the simplest and least derived plant gall within the wide variety of these structures found in Nature. On the other hand, galls induced by insects are very wellorganized structures showing different degrees of differentiation, the reason why they are considered as the most complex and derived structures. Nonetheless, in spite of the clear differences between these two extremely diverse groups of plant galls, they show important similarities. For instance, both systems require a previous state of "conditioning" towards the development of the structure. In the case of insect galls, the "conditioner" is the insect itself, which modulates the tissue that will form the structure through mechanical action and the secretion of chemical substances. In crown galls the conditioning factor is given by a series of metabolic events prior to the genetic transformation of plant cells by the bacterium (Rohfritsch \& Shorthouse, 1982; Davey et al., 1994; Piñol, Palazón, Cusidó \& Serrano, 1996; Valentine, 2003; Suzuki et al., 2015).

In a similar manner as in so-called "tumor cells" of crown galls, cells from insect-induced galls acquire a certain autonomy and independence from their normal tissue development pattern. From the induction process, cell development is redirected due to the influence of the inducing stimulus. However, unlike insect galls, crown galls have an unlimited capacity to grow without a defined pattern of development. After the initial stimulus, cell proliferation in both systems develops in a different way; in the case of bacteria-induced crown galls, cell proliferation occurs in an uncontrolled way and does not require the continuous presence of bacteria once the process is initiated. In contrast, for adequate and complete development of galls induced by insects, in general, the continuous, active presence of the insect is required (Rohfritsch \& Shorthouse, 1982; Davey et al., 1994; Valentine, 2003; Suzuki et al., 2015).

According to Rohfritsch \& Shorthouse (1992), Arduin \& Kraus (1995), and Sá et al. (2009), plant galls present four basic stages of development, but significant differences between gall inducers can occur. These stages of development involve the processes of initiation, growth and differentiation, maturation, and finally, dehiscence (Fig. 3). The state of growth and development is a continuous process of cell division and differentiation that generally depends on the feeding activity of the larva, which in turn is mainly responsible for molding the shape of the gall's inner chamber. After the nutritive tissue is formed around the inner chamber, a mass of cells binds the vascular tissue of the gall to the plant. Frequently, sclerenchymatous tissue is also formed around 


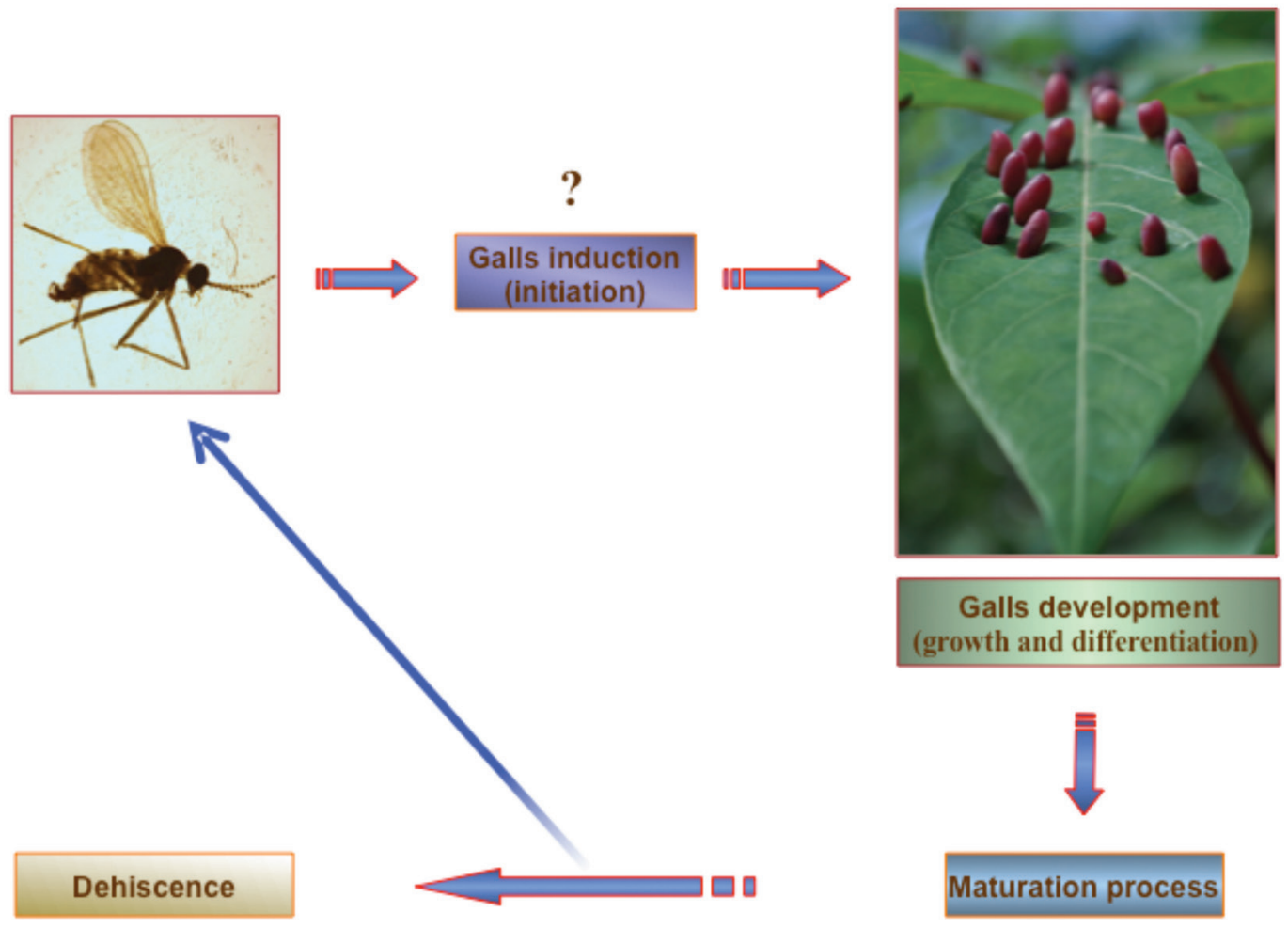

Fig. 3. General scheme for the life cycle of insect-induced galls. This figure is based on the gall induced by the Cecidomyiidae Latrophobia brasiliensis in Manihot esculenta Crantz (Cassava). The scheme was synthesized from the reviewed literature. Photo credit: Omar Gätjens-Boniche.

the inner chamber and near the vascular tissue of the gall, which causes its separation into internal and external regions. The internal region is considered to be influenced by the activity of the larva, whereas the external region or outer cortex of the gall is under the influence of the plant. The opening and dehiscence of galls occurs towards the end of the maturation stage and represents the period of greatest chemical and physiological change in the tissues that comprise it. Not only has it been demonstrated that the meristematic tissues react to the stimuli but also that young stems of various species of plants can be stimulated and modified to make these structures.

Shorthouse \& Rohfritsch (1992) separate the morphogenesis of galls induced by insects into two processes. The first is a permanent effect, which remains even when the corresponding insect is removed or dies. A second process implies that the effect is generated through continuous stimulation by the inducing insect, which disappears if the insect is removed from the gall or if it dies.

Several authors have tried to classify galls according to a series of morphological criteria that have, in spite of being arbitrary, established the groundwork for the development of a great number of studies. Shorthouse \& Rohfritsch (1992) and Williams (1994) distinguished two basic types of galls: organoids and histoids. The first one results from organ proliferation or modification, maintaining the basic organ structure. Histoid galls, in contrast, originate from the proliferation of modified cells leading to the formation of new tissue. Plant galls are also classified according to more strict morphological criteria. Galls called "kataplasmic" are irregular in size and shape, presenting an irregular growth pattern 
with little differentiation in their tissues. On the other hand, "prosoplasmic" galls are more complex and differentiated and are formed as a result of the formation of a new structure (Miles, 1968; Williams, 1994). Nonetheless, it is important to emphasize that any attempt at classification turns into a difficult task, mainly because of the great quantity of existing intermediate states and shapes among the different gall morphotypes. Therefore, the shape and structure of galls depends on a large number of factors, including the species to which the host plants belong, the species of the inducing insects, the type of organ attacked, the state of development of the plant and, in some cases, even the sex of the insect. According to Raman (2011), about $90 \%$ of all the known galls show bilateral or radial symmetry. As reported by the same authors, in the specific case of galls formed by insects belonging to the families of Cecidomyiidae (Diptera) and Cynipidae (Hymenoptera), they show surprising levels of radial symmetry. Moreover, some factors that affect gall size include the number of larvae present, the structural diversity of the galls, the percentage of tissue infected, the physiological state of the host plant, environmental conditions, and the genotype of the plant (Mani, 1992; Ananthakrishnan, 1998; Stone \& Schönrogge, 2003; Raman, 2011).

Some galls are simply "swellings" - undifferentiated cell masses or those with a low level of differentiation, while others show a surprisingly high degree of differentiation, organization and specialization within their cells and tissues, frequently with characteristics exclusively associated with the gall from which they originate. Based on the above, this last type of gall, called "prosoplasmic", presents an anatomy and histology very characteristic of its own. Prosoplasmic galls induced by some families of insects are, due to their high degree of complexity and organization, the ones that generate a higher interest (Mani, 1992).

The order Hymenoptera includes the most complex and organized galls described so far for the Class Insecta. In this group, gallinducing insects are classified in the Suborder
Symphyta, family Tenthredinidae and the Suborder Apocrita, with two Superfamilies: Chalcidoidea, which includes the families Pteromalidae, Eurytomidae, and Agaonidae and the superfamily Cynipoidea, represented by the family Cynipidae. Gall-inducing Hymenoptera species present a wide distribution over several areas of the planet and can be found in various groups of dicotyledonous plants and even in monocotyledonous plants, especially in gramineous species (Shorthouse \& Rohfritsch, 1992). According to Rohfritsch \& Shorthouse (1982) and Shorthouse \& Rohfritsch (1992), Cynipidae contains the main gall inducers of the order Hymenoptera, and they can cause the development of different kinds of galls in distinct organs of the plant. Most representatives of this family induce the formation of galls in leaves, sprouts, stems, and roots. Females lay eggs on the surface of the tissue, and the egg itself induces an initial gall, even though the larvae of these insects are the main inducing agents of these structures. Cynipidae eggs have a lytic effect on the cells that surround them, which leads to the formation of a chamber that protects the young larva. Larvae have mouth structures that allow them to break the plant cell wall to suck on the contents of the nutritive cells. Many species of Cynipids are characterized by complex life cycles, commonly accompanied by an alternation of generations. Individuals of both generations can attack the same organ or different types of organs in the plant, resulting in the formation of radically different galls, and in some cases, even the individuals of the two generations are morphologically different. The surface of the galls formed by the Cynipids can be coated by trichomes, scales, thorns, or other types of outgrowths. Nevertheless, one of the most important characteristics of these structures is the formation of concentric areas of differentiation and an area of sclerenchymatous cells around the larval chamber.

The order Diptera grouped in the suborder Nematocera, which includes the family Cecidomyiidae (gall midges), and the suborder Brachycera, which includes Tephritidae (fruit 
flies) and Agromyzidae. Gall inducers belonging to this order present a broad global distribution, and in contrast to other orders of gall- inducing insects, they can also be found in monocotyledonous plants, especially grasses. Nonetheless, the majority of arthropod-induced galls occur on dicotyledons, and at least 66 $\%$ of the dicotyledon families harbor galls (Shorthouse \& Rohfritsch, 1992; Hanson \& Gómez-Laurito, 2005). Hanson \& GómezLaurito (2005) suggested that possibly more than $90 \%$ of dicotyledon species in all major biogeographic regions harbor gall-inducing by cecidomyiids. Around $80 \%$ of plant galls induced by insects from the Neotropical region are induced by the Cecidomyiidae family, and new species of inducing insects belonging to this family are constantly being described around the world. Moreover, according to Hanson \& Gómez-Laurito (2005), about $70 \%$ of the gall-inducing arthropods in Costa Rica are Cecidomyiidae.

Galls formed by Diptera, especially those induced by individuals of the family Cecidomyiidae, are characterized by a high degree of tissue differentiation; on the other hand, the insects are characterized by the complexity of their life cycles. Another important characteristic present in gall-inducing Diptera species is their capacity to pupate inside the gall. In the family Cecidomyiidae only the larvae have the capacity to induce galls; these have a poorly developed mouth structure and feed by sucking on fluids exuded from the gall cells, without causing any damage or necrosis (Rohfritsch \& Shorthouse, 1982; Shorthouse \& Rohfritsch, 1992). In those galls, nutritive tissue is present throughout the development of the structure. At the same time, for the development and maintenance of nutritive tissue, the active presence of the larva of the inducing insect is necessary (Ananthakrishnan, 1998).

Galls induced by the orders Thysanoptera and Hemiptera appear as small bumps or abnormal growths, whose tissues are essentially made of parenchymatous cells. Some species can also cause a leaf roll accompanied by cellular hypertrophy. In the case of the hemipterans, they induce a variety galls types, which vary from simple forms to very sophisticated complex structures. Several species of coleopteran gall-inducing larvae produce tunnels in different parts of the plants, and the eggs are placed in the interior of cavities prepared by insect females. Although plant galls induced by Coleoptera have been described as characterized by the absence of nutritive tissue (Shorthouse \& Rohfritsch, 1992), there are descriptions detailing the presence of this type of tissue or nutritive-like tissue in coleopteran galls (Raman et al., 2007; Barnewall \& De ClerckFloate, 2012). Nevertheless, little is known about gall-inducing Coleoptera, especially in tropical ecosystems (Korotyaev, Konstantinov, Lingafelter, Mandelshtam, \& Volkovitsh, 2005). Many galls formed by Lepidoptera do not develop nutritive tissue, and larvae of these insects are fed by chewing the tissue that surrounds the internal chamber, producing a large amount of detritus (Rohfritsch \& Shorthouse, 1982; Shorthouse \& Rohfritsch, 1992). However, recent studies on lepidopteran-induced galls suggest that these structures may also present nutritive tissue and are not as simple as they have traditionally been described. For example, a true nutritive tissue that showed metabolite concentration gradients, which seem to be specific for lepidopteran galls, was described by Ferreira \& Isaias (2013). Nutritive tissue was described in Bauhinia ungulata L. (Fabaceae) by Bedetti, Ferreira, de Castro, and dos Santos Isaias (2013). Moreover, nutritive cells in the galls induced on the leaves of Tibouchina pulchra (Cham.) Cogn. (Melastomataceae) have a large amount of rough endoplasmic reticulum, ribosomes, polyribosomes, and mitochondria, which are evidence of the high metabolic status of these cells. Likewise, vascular cambiumlike, with high protein synthesis and lipid storage, are characteristic of that nutritious tissue. The nutritive cells are stimulated by the activity of galling larvae, consequently generating a new tissue type (Vecchi, Menezes, Oliveira, Ferreira, \& Isaias, 2013). 


\section{The induction mechanism of plant galls by insects: What do we know?}

The capacity of a large number of insects to form galls in different groups of plants has motivated a great deal of research with the aim of elucidating the mechanism of induction of this type of structure. Hori (1992) describes four main hypotheses that could explain the formation of plant galls. The first of these hypotheses suggests the injection of a fluid from the insect during the oviposition process, which would mediate gall induction. A second hypothesis proposes that gall formation is the result of mechanical irritation due to the presence of a foreign body on the plant tissue. An extension of this hypothesis suggests that galls are induced at a "reactive site" with particular traits of available meristematic regions by the action of the inductor insect, probably in stem cell areas (Weis, Waltonanand, \& Crego, 1988; Abrahamson \& Weis, 1997; Espírito-Santo, Neves, Andrade-Neto, \& Fernandes, 2007; Silvia \& Connor, 2017). The third hypothesis proposes that the formation of galls is induced by the secretion of active components from the saliva of the insect. Finally, a fourth hypothesis purports that the formation of galls is mediated by the excretion of metabolic products from the insect.

For simplicity, the morphogenic process of plant gall induction by insects can be divided into three main phases. The first one involves "conditioning" of the cells of the corresponding plant tissue by the insect, to make them more susceptible and suited to its action as inductor. In the following phase, induction of the gall as such takes place, whereby cell division and elongation results in the formation of a "primary" gall. The final phase consists of gall maturation, in which the primary gall grows to complete its morphogenesis (Shorthouse \& Rohfritsch, 1992; Raman, 2011).

As mentioned above, in the plant gall induction process, plant cells should be conditioned to produce a particular physiological state (Raman, 2011). In this respect, different studies have mentioned that the amino acids present in the salivary secretions of gall-inducing insects, essentially lysine, histidine, and tryptophan, could function as "preconditioners" for gall induction. It seems that these amino acids could cause major plasticity and would increase the sensitivity of the plant tissue to the action of the corresponding inducing insect. Although the presence of pectinase in the saliva of insects has not been correlated with gall induction, such enzymes could degrade the cell walls and in turn contribute to tissue preconditioning to the action of the insect. Likewise, it has been speculated that polyphenol oxidase (PPO), also present in the saliva secretions of insects and the phenolic compounds derived from its enzymatic action, could increase plant tissue sensitivity to the stimulus of the inductor insect. It has also been suggested that the complex interaction between the host plant tissue and polyphenol oxidase might be of fundamental value in gall formation (Miles, 1968; Hori, 1992; Ananthakrishnan, 1998; Saltzmann, Giovanini, Zheng, \& Williams, 2008). In this respect, Miles (1968) indicated that interactions and the balance between insect polyphenol oxidase and the host plant could determine whether the "attack" of an insect causes injury (necrosis) or gall development. Moreover, the modulation of redox potential has been related to gall initiation and establishment, especially concerning the accumulation of reactive oxygen species (Isaias, Oliveira, Moreira, Soares, \& Carneiro, 2015).

Different studies have reported that indoleacetic acid (IAA) could be a powerful gallinducing agent, and it has also been speculated that this compound could interact with other plant growth regulators, like cytokinins and gibberellins, or in a synergistic way with other chemical substances, to promote the induction and maturation of these structures (McCalla, Genthe, \& Hovanitz, 1961; Miles, 1968; Hori, 1992; Leitch, 1994; Ananthakrishnan, 1998; Mapes \& Davies, 2001; Stone \& Schönrogge, 2003; Raman, 2011, Tooker, \& Helms, 2014; Bartlett \& Connor, 2014; Bedetti, Modolo, \& dos Santos, 2014; Bailey, Percy, Hefer, \& Cronk, 2015). However, the mechanism of 
action through which these substances act to promote the development of plant galls is very poorly understood and is currently a subject of discussion. This scenario becomes more complicated in the case of prosoplasmic galls, like the ones formed by insects of the Cecidomyiidae and Cynipidae families, because of the complexity of their development and structure.

Symbiotic relationships between gallinducing insects and microorganisms have been hypothesized to be involved in plant gall development (Hansen \& Moran, 2014; Tooker and Helms, 2014). Several studies have demonstrated the presence of a great number of endosymbiotic bacteria in different insect groups (Degnan, Lazarus, \& Wernegreen, 2005; Kikuchi, Meng \& Fukatsu, 2005; Delmotte, Rispe, Schaber, Silva, \& Moya, 2006; Fukatsu et al., 2007; Jaenike, Polak, Fiskin, Helou, \& Minhas, 2007; Goto, Anbutsu, \& Fukutsa, 2006; Xi, Gavotte, Xie, \& Dobson, 2008; Toft, Williams, \& Fares, 2009; Gutzwiller, Dedeine, Káiser, \& Giron, 2015; Krawczyk, Szymańczyk, \& Obrępalska-Stęplowska, 2015; El-Sayed \& Ibrahim, 2015; Campbell et al., 2015), as well as bacteriocytes (Nikoh \& Nakabachi, 2009; Braendle et al., 2009). Some of these symbiont microorganisms are mutualistic and contribute to the viability of their hosts, while others are parasites, which tend to affect their corresponding hosts in a negative way. Insect-associated microorganisms could be important mediators of interactions between insects and plants (Sugio, Dubreuil, Giron, \& Simon, 2015; Hammer \& Bowers, 2015, Wielkopolan \& Obrępalska-Stęplowska, 2016). Some researchers have reported that simultaneous infection with different species of endosymbionts in the same host organism is a common phenomenon in several insect groups (Thao et al., 2000; Thao, Gullan, \& Baumann, 2002; Russell et al., 2003; Ishii, Matsuura, Kakizawa, Nikoh, \& Fukatsu, 2013; Krawczyk et al., 2015; El-Sayed et al., 2015; Ghosh, Bouvaine, \& Maruthi, 2015; Brentassi et al., 2017). Different tissues in the body of the same host constitute different microenvironments for endosymbiont organisms. Some tissues could be, for instance, nutritionally favorable, immunotolerant, or simply easy to colonize (Mouton, Henri, Bouletreau, \& Vavre, 2003; Kondo, Shimada, \& Fukatsu, 2005; Koga, Meng, Tsuchida, \& Fukatsu, 2012; Hansen \& Moran, 2014; Sugio et al., 2015).

In recent years, a growing interest has emerged regarding the reproductive biology of endosymbiont parasites that are transmitted through the mother and manipulate the reproduction of their host organism. Accumulated evidence shows that many species of arthropod are infected by different kinds endosymbiont organisms transmitted from the mother through vertical transmission, which have a great influence on the biology of their hosts. Some of these endosymbiont microorganisms include Wolbachia, Spiroplasma, Rickettsia, Arsenophonus, and Cardinium, among others (Weeks, Velten \& Stouthamer, 2003; Zchori-Fein \& Perlman, 2004; Goto et al., 2006; CasperLindley et al., 2011; Goodacre \& Martin, 2012; Kageyama, Narita, \& Watanabe, 2012; Koga et al., 2012; Kremer et al., 2012; Herren, Paredes, Schüpfer, \& Lemaitre, 2013; Ma, Vavre \& Beukeboom, 2014; Boivin et al., 2014; Ma et al., 2015; Sugio et al., 2015; Brentassi et al., 2017; Mariño, Verle Rodrigues, \& Bayman, 2017; Ma \& Schwander, 2017).

Many galling insects are known to have microbial associates that may be involved in gall development or could facilitate herbivory, such as Ambrosia gall midges associated with fungal symbionts, but studies exploring the role of microbial associates in the lifecycles of insect gallers are scarce (Hansen \& Moran, 2014; Tooker \& Helms, 2014; Huang et al., 2015). Bacteria of the genus Wolbachia have been associated with green-island formation by the apple leaf-mining moth Phyllonorycter blancardella, a similar phenomenon to the one observed in some types of plant galls induced by insects (Kaiser, Huguet, Casas, Commin, \& Giron, 2010; Gutzwiller et al., 2015). Their results suggest that bacteria impact greenisland induction by manipulating cytokinin levels. In addition, secretions of phytohormones, such as cytokinins, by endosymbiotic 
microorganisms have also been associated with the plant-galling insect interaction (Spíchal, 2012). Likewise, Bartlett and Connor (2014) hypothesized that the inducing insects obtained their ability to induce galls via endosymbiotic microbes, which have acquired the biosynthetic pathways to produce IAA and trans-zeatin family cytokinins from plants. It is not surprising then that the control of cytokinins constitutes an important selection factor for arthropods and pathogens because of the importance of these phytohormones in the regulation of plant morphology, senescence, and defense, especially with regard to the mobilization of nutrients in each of these processes (Giron, Frago, Glevarec, Pieterse, \& Dicke, 2013; Tooker \& Helms, 2014; Naseem, Wölfling, \& Dandekar, 2014; Giron et al., 2016).

It has been proposed that galling insects acquired genes from symbiotic microorganisms through horizontal gene transfer (Giron \& Glevarec, 2014; Bartlett \& Connor, 2014). Horizontal gene transfer (HGT) is the movement and transference of genetic information between different organisms, and it is a common phenomenon between pathogens of animals and plants, and between symbionts and pathogens (De la Cruz \& Davies, 2000; Suzuki et al., 2015). Indirect evidence supporting the previous hypothesis is provided by works such as those carried out by Nikoh et al. (2008). Molecular analyses performed by these authors in Wolbachia, one of the most abundant intracellular bacteria described in arthropods, as well as nematodes, suggested that approximately $30 \%$ of Wolbachia genes are present in the nuclear genome of host insects. In this study, through fluorescence in situ hybridization techniques, they located the transferred genes of Wolbachia in the proximal region of the short arm of the insect $\mathrm{X}$ chromosome. The collected evidence indicated that this process of horizontal gene transfer was probably generated from an individual event. In another study, it was determined that the genome of Wolbachia pipientis contains high levels of repetitive sequences of DNA and also mobile genetic elements (Wu et al., 2004). In spite of its wide distribution and the effects of Wolbachia on the biology of its hosts, little is known about the molecular mechanisms that mediate the interaction between this bacterium and its invertebrate hosts (Wu et al., 2004; Chrostek \& Teixeira, 2015).

Therefore, under the previous scenario, horizontal gene transfer (HGT) could play a fundamental roll in plant gall induction and evolution. In recent years, more evidence has shown that the molecular mechanisms involved in the different processes of symbiosis and pathogenesis present a series of common pathways which have revealed existing similarities in the modulation and interactions between pathogens and symbionts with their hosts (De la Cruz \& Davies, 2000; Hentschel, Steiner, \& Hacker, 2000; Rankin, Rocha, \& Brown, 2011; Suzuki et al., 2015). Furthermore, the information generated by microbial genome sequencing studies has demonstrated that horizontal transference of genes is an important process and widely distributed within the evolutionary scenario of prokaryote organisms (Nikoh \& Nakabachi, 2009; Jayaprakashvel, Bhrathi, Muthezhilan, \& Hussain, 2017).

In addition to chromosomes, prokaryotes possess mobile genetic elements, such as genomic islands, plasmids, transposons, insertion sequences or bacteriophages, which allow them to induce structural and physiological changes, as well as the acquisition or loss of genomic regions. Moreover, the fact that a great number of pathogenic and symbiotic determinants are located in mobile genetic elements allows a source of permanent variation to be generated within these organisms. In addition, some authors have suggested that the acquisition and incorporation of plasmids into bacteria could constitute a key process to the adaption of these microorganisms to new ecological niches and to their development as symbionts or pathogens (Vivian, Murillo, \& Jackson, 2001; Suzuki et al., 2015; Jayaprakashvel et al., 2017). Genetic variability plays a very important role by generating the conditions that allow the evolution of new types of interactions among organisms, thus HGT between different 
species could represent a powerful mechanism through which the final result of the interaction between a pathogen or symbiont and its host could be altered permanently (Hentschel et al., 2000; Suzuki et al., 2015; von Wintersdorff et al., 2016; Porse, Schou, Munck, Ellabaan, \& Sommer, 2018).

Not only is HGT responsible for speciation and subspeciation in bacteria; it also constitutes an important mechanism in eukaryote organisms. There are sufficient information related to the role of conjugation processes in the transference of genetic information from bacteria to eukaryote cells. Such eukaryote cells include yeasts, filamentous fungi, and plant cells (De la Cruz \& Davies, 2000; Rankin et al., 2011; Suzuki et al., 2015). For example, the mechanism through which Agrobacterium tumefaciens transfers genes from the bacterium to plant cells is well known: it occurs through the action of the T-DNA segment present in the Ti plasmid (Suzuki et al., 2015). Stable natural transgenic plants of sweet potato containing Agrobacterium T-DNA sequences with their foreign genes expressed at detectable levels in different tissues were reported by Kyndt et al. (2015). Likewise, the work of Diao, Freeling, \& Lisch (2006), provides evidence of HGT through the transposons of superior plants. In this regard, some bacteria, retroviruses, and DNA viruses constantly integrate different kinds of genetic elements into the chromosomes of animal and plant cells through mechanisms such as conjugation and transformation (De la Cruz \& Davies, 2000, Oliver et al., 2006; Klasson, Kambris, Cook, Walter, \& Sinkins, 2009; Nikoh \& Nakabachi, 2009; Suzuki et al., 2015). Moreover, the mechanism by which eukaryotes acquire genes from distantly related organisms remains obscure (Suzuki et al., 2015).

Although, in general terms, it has been accepted that some kind of "chemical stimuli" (very likely a phytohormone) from the insect is involved in the induction and morphogenesis of galls (McCalla et al., 1961; Miles, 1968; Rohfritsch \& Shorthouse, 1982; Hori, 1992; Leitch, 1994; Ananthakrishnan, 1998; Raman, 2011; Yamaguchi et al., 2012; Connor et al.,
2012; Erb, Meldau \& Howe, 2012; Giron et al., 2013, Tooker \& Helms, 2014; Bailey et al., 2015; Oates et al., 2016, Giron et al., 2016), up to now it has not been possible to determine with certainty whether insects could synthesize phytohormones. However, Yamaguchi et al. (2012) found abnormally high concentrations of a type of zeatine in the glands of the "sawfly" Pontania sp. (Hymenoptera, suborder Symphyta) which, according to these researchers' criteria could be strong evidence that this insect can synthesize cytokinins as well as IAA. Likewise, Shih, Lin, Huang, Sung, and Yang (2018) found evidence that gall induction could be related to the secretion of phytohormones like cytokinin and auxin, as well as Brassinosteroids (steroids hormones), from the inductor insect. In a similar direction, Bartlett \& Connor (2014) showed evidence consistent with the hypothesis that exogenous cytokinins, in combination with IAA from the gall-inducing insect, lead to gall induction. Additionally, Brütting et al. (2018) demonstrated, using ${ }^{15} \mathrm{~N}$-isotope labeling, the transference of the cytokinin $\mathrm{N}^{6}$-isopentenyladenine (IP) from the free-living herbivore and non-galling insect Tupiocoris notatus to Nicotiana attenuata plants via their oral secretions.

On the other hand, the possibility of a molecular induction mechanism in insectinduced plant galls that involves the transference of genetic elements has neither been considered nor explored extensively. Cornell (1983) suggested the possibility that the gallinducing insect could insert some genetic elements, mutualistic viroid, or virus into the plant genome, which would regulate and control the process of gall formation. However, this author did not offer any evidence that could support this statement. The molecular basis of the induction of plant galls by insects is still unknown (Stone \& Schönrogge, 2003; Raman, 2011; Oates et al., 2016; Bailey et al., 2015; Giron et al., 2016). Moreover, the physiological nature of the stimuli given by the inducing insect and the influence of its own genomic constitution, as well as the reaction generated 
by the plant, are questions that remain completely open.

Stone \& Schönrogge (2003) mentioned three great problems or challenges in identifying the molecules responsible for the process of gall formation. First is the difficulty of establishing an appropriate assay for the plant tissues involved in the process of induction. Second, the possible inducing molecules used by insects could be chemically similar to those normally present in the plant. Third, since it is expected that the signals coming from the insect generate a cascade of responses in the plant, it would be very difficult to separate the first morphogenetic impact originated by the inductor from the secondary responses generated by the plant.

In the particular case of gall-inducing insects belonging to Cecidomyiidae, it has been reported that either the egg or the ovipositing female could generate the initial stimulus and that the larva, by secreting substances that promote the growth of plant tissue under its action, could cause the formation of the gall (Hori, 1992).

Regarding the family Cynipidae (Hymenoptera), different studies have associated both auxins and cytokinins with the processes of gall induction and morphogenesis. Moreover, the morphogenesis and induction of these structures have been correlated with the activity of oviposition of the female, secretions of the insect egg, and the activity and secretion of chemical substances from the larva (Miles, 1968; Hori, 1992, Shorthouse \& Rohfritsch, 1992; Raman, 2011). As with the galls formed by insects from the family Cecidomyiidae, the mechanism of morphogenesis of galls formed by cynipids cannot be explained simply by the action of plant phytohormones. Nevertheless, Boysen-Jensen (1952) and Miles (1968) support the hypothesis of chemical induction, arguing that the larva moves instinctively and secretes regulatory substances in the proper locations of the "attacked" tissue at specific times, thereby generating a suitable environment that favors the development of the gall.
"Omics" is an informal term that refers to fields of study in biology ending in -omics, such as genomics, proteomics, or metabolomics, among others. Emerging work conducted with new omics technologies is expanding our understanding of some relevant aspects relating to plant gall induction and morphogenesis. In a recent paper regarding the identification of the galling effector repertoires of the Hessian fly, it was shown that around $7 \%$ of its genome encodes putative effector proteins, which include the secreted salivary gland protein (SSGP)-71, a known member of an arthropod protein family (Zhao et al., 2015). Moreover, these authors showed that although SSGP-71 lacks sequence homology with other proteins, its structure resembles both ubiquitin E3 ligases from plants and E3-ligasemimicking effectors from plant pathogenic bacteria. Protein analyses indicate that the mature SSGP-71 protein contains a cyclin-like $\mathrm{F}$ box domain near the $\mathrm{N}$-terminus and a series of leucine-rich repeats (LRRs). F box domains are frequently associated with LRRs, and both domains mediate protein-protein interactions, according to Ho, Tsai, and Chien (2006). These types of proteins are associated with the transfer of ubiquitin to target proteins destined for degradation in the proteasome. In addition, they play essential roles in phytohormonal signaling, plant development, and plant immunity. Zhao et al. (2015) also proposed that SSGP-71 proteins are a novel class of F-box-LRR mimics that enable the insect to hijack the plant proteasome in order to directly produce nutritive tissue and additionally defeat basal plant immunity. These authors further propose that their results prove that these effectors are the agents responsible for arthropod-induced plant gall formation. Likewise, Shih et al. (2018) demonstrated, by using transcriptome analysis, the modification of normal plant tissue to form galls. Moreover, they indicated that the manipulation of genes related to gall formation might be induced by auxin, cytokinin, and even steroid hormones (Brassinosteroids) secreted by gallers of Hemiptera, Lepidoptera, and Diptera. Similarly, other transcriptomic and 
genomic studies provide evidence leading to altered gene expression in galled plant tissues. These altered genes and effector proteins could be involved in several aspects of gall insect biology, including feeding, metabolic alterations, suppression of defense responses, and developmental manipulation of the host plant tissue (Rawat, Neeraja, Nair, \& Bentur, 2012; Hearn, 2013). Even more interesting, Hearn (2013) also determined that genes expressed in gall wasp genomes encode plant-cell-walldegrading enzymes that could originate from plant pathogenic bacteria. Pawłowski, Staszak, Karolewski, and Giertych (2017), using a proteomic approach to compare the galls induced by three oak gall species, Cynips quercusfolii, Cynips longiventris, and Neuroterus quercusbaccarum, with non-gall plant tissue in the host plant Quercus robur, described several proteins that could potentially be related to plant gall formation. On the other hand, for non-insect galls, a transcriptomic approach by Olszak et al. (2018) showed evidence that galls induced by Plasmodiophora brassicae in Arabidopsis reprogram critical steps of the host cell cycle. That distortion leads to initial cell hyperplasia, which increases the number of cells, followed by overgrowth of cells colonized by the pathogen. The authors showed that $P$. brassicae infection stimulates the formation of the $\mathrm{E} 2 \mathrm{Fa} /$ RBR1 complex and upregulation of MYB3R1, MYB3R4, and A- and B-type cyclin expression. Those cell cycle factors were previously described as important regulators of the G2-M cell cycle checkpoint.

An interesting survey in nematode galls (Meloidogyne incognita), using high throughput sequencing for small non-coding RNAs, identified siRNA clusters that were differentially expressed in infected roots of Arabidopsis thaliana. Those siRNAs were overrepresented in infected tissue, with a size 23 - 24 nt, corresponding to heterochromatic siRNAs (hcsiRNAs), which are known to regulate the expression of transposons and probably genes at the transcriptional level, by an RNA-directed DNA methylation (RdDM) pathway that induces the silencing of transposable elements (Medina et al., 2018).

\section{Insect-induced plant galls and phytochemistry}

An interesting aspect of some plant galls is the particular or even radical phytochemistry between these structures and normal plant tissues. Research conducted on galls of different species of plants have revealed that the composition and concentration of chemical substances in these structures can differ from those of other plant tissues and organs (Tooker \& de Moraes, 2008; Saltzmann et al., 2008; Giron \& Huguet, 2011; Huang et al., 2015; Oates et al., 2015; Hall, Carrol, \& Kitching, 2017; Kot, Jakubczyk, Karaś, \& Złotek, 2017). Tissues near the outside of the gall frequently accumulate high levels of tannins and other chemical compounds related to the process of defense of the gall and, in consequence, of the insect (Ananthakrishnan, 1998; Li et al., 2017; Chen et al., 2018; Nogueira et al., 2018). A study by Vereecke et al. (1997) revealed that the chemical composition of ethanol and aqueous extracts of galls produced in the leaves of Nicotiana tabacum differs drastically from that of non-infected plant tissue extracts. It has been reported that the concentrations of some carbohydrates such as hemicellulose, xylose, and arabinose increase during gall development in the tree Zelcowa (Yeo, Chae, So, Lee, \& Sakurai, 1997). Other authors have also reported differences in the concentrations of certain secondary compounds as well as certain types of phytohormones in plant gall tissue (Kraus \& Spiteller, 1997; Pinkwart, Diettrich, \& Luckner, 1998). Kot et al. (2017), Li et al. (2017) and Hall et al. (2017) demonstrated that galls induced by cynipid species and the wasp Leptocybe invasa (Hymenoptera: Eulophidae), respectively, contain high levels of phenolic compounds compared with control tissues. Moreover, increased production of waxes in the gall induced by the insect Baccharopelma spp. (Hemiptera: Psyllidae) in leaves of Baccharis spicata (Lam) Baill has been related 
to a protective function against desiccation by Agudelo et al. (2018).

Several authors have reported high concentrations of certain nutritive substances in gall tissues; some of those substances include sugars, proteins, phosphates, lipids, and nitrogen compounds (Tooker et al., 2008; Giron \& Huguet, 2011; Huang et al., 2015; Li et al., 2017). In contrast, some researchers have described that galls can present low levels of certain chemical compounds related to the processes of plant defense, such as some phenolic compounds (Price et al., 1986; Agudelo et al., 2018).

Due to the fact that many galls present high quantities of certain nutrients and low levels of other chemical substances that are damaging to insects, a hypothesis has been proposed related to the galler being able to manipulate the development of its host plant by generating a tissue with a higher nutrient value (nutritional hypothesis). Nevertheless, several studies conducted with the goal of proving this hypothesis revealed that the concentrations of certain chemical compounds considered as defensive in plants are higher in the gall tissues, which is contrary to the above-mentioned hypothesis and suggests the need for a reconsideration of the same (Nyman \& Julkunen, 2000).

Taking into consideration studies such as the those carried out by Nyman \& Julkunen (2000), Tooker \& De Moraes (2008), Tooker et al. (2008), Giron \& Huguet (2011), Huang et al. (2015), Oates et al. (2015), Li et al. (2017), Kot et al. (2017), Chen et al. (2018), and Agudelo et al. (2018), comparing the chemical composition of galls with that of normal plant tissue, the conclusion would be that gall-inducing insects could control some the chemical properties of these structures.

\section{CONCLUSIONS AND PERSPECTIVES}

Although the chemical induction hypothesis has been accepted with some discretion and questioning as the general mechanism of plant gall induction, there are, so far, no related studies on a putative induction mechanism involving exogenous genetic elements in the process of insect gall formation. Moreover, little has been speculated in relation to this topic. A possibility exists that the control of induction and morphogenesis of insect galls could be under strict genetic control, possibly mediated by the insertion of mobile genetic elements into the genome of plant gall cells. Likewise, that process could be mediated by means of an endosymbiotic bacteria from the insect. Thus, due to the demonstrated ability of the inductor to manipulate the process of morphogenesis in insect galls, the galling insect should be able to control the regulation and expression of those exogenous insertion sequences at different levels. Consequently, under this hypothetical scenario, the insertion sequences would function as mediators of the molecular interaction between animal and plant systems. Genes contained in these possible insertion sequences could be those related to the control of the host cellular machinery and analogous phytohormones genes to those present in the host plant, among others. Virtually no work has been conducted in this direction, probably because of insufficient knowledge and the complexity of insect-plant-gall system relationships.

On the other hand, if a relatively simpler plant gall induced by Agrobacterium species involves a complex interaction between the inductor organism and its host plant, which is mediated by the insertion of genetic elements into the genome of the host cells, why is it not then assumed that a similar or even more complex mechanism exists for the induction of more complex plant galls, which could also be induced by the delivery of genetic elements from the cecidogenic organism? We could also rephrase the question as follows: is cellular self-proliferation an essential requirement or condition for the genetic transformation of plant cells, as occurs in the case of "crown galls" induced by Agrobacterium?

It is essential to conduct studies to understand, at the molecular level, the mechanism of induction and morphogenesis of plant galls induced by insects, exploring the presence of any possible symbiotic organism and some 
kind of external genetic element to the plant gall cells, associated with any of the symbionts. With this goal in mind, an appropriate gall induction model system should be chosen. The choice of an insect-plant gall system to be used as an experimental model should take into account gall diversity and morphologic complexity in order to include, in the same plant species, prosoplasmic and kataplasmic gall types. The next step would be to compare the similarities and differences at the molecular level, among different kinds of galls and how these could affect the extraordinary morphology and diversity observed in nature. Due to the diversity of shapes, colors, and complex structures displayed by insect galls, these systems could constitute ideal models to study how form and structure are determined at the molecular level in biological systems, more specifically, taking as a parameter plant morphology.

Due to their physiological and biochemical particularities, the identification of chemical substances or even specific genes in plant galls that could be of interest or have practical applications, according to the genetic transformation hypothesis postulated in this article, could result in these tissues becoming real germplasm sources, which may have a great impact on conservation policies and offer a promising background for the development of applied biotechnologies. Considering all the above information, it is clear that plant galls represent an important germplasm sink and a promissory gene bank that should be explored, used, and preserved as an authentic treasure of our biodiversity.

\section{RESUMEN}

El mecanismo de inducción de agallas de plantas por insectos: revelando claves, hechos y consecuencias en una interacción compleja entre reinos. Las agallas se definen como modificaciones del diseño y desarrollo normal de las plantas debido a una reacción específica a la presencia y actividad de un organismo foráneo. Aunque diferentes grupos de organismos tienen la habilidad de inducir agallas en plantas, las agallas inducidas por insectos son las más elaboradas y diversas. Algunas hipótesis han sido propuestas para explicar el mecanismo de inducción de las agallas de insectos. La hipótesis más general sugiere que la formación de las agallas es disparada por la acción de sustancias químicas secretadas por el insecto inductor, incluyendo reguladores de plantas como auxinas, citoquininas, ácido-3-indolacético (AIA) o bien otros tipos de compuestos. No obstante, el modo de acción de estas sustancias químicas y el mecanismo general por medio del cual el insecto podría controlar y manipular el desarrollo y fisiología de la planta es aún desconocido. Más aún, como resultado de la complejidad del proceso de inducción y desarrollo de las agallas de plantas inducidas por insectos, la hipótesis química es una explicación insuficiente e incompleta en relación con el mecanismo de inducción y morfogénesis de estas estructuras. Previas y nuevas evidencias relacionadas con el sistema de agallas de insectos, con énfasis en el proceso de inducción, fueron analizadas desde un punto de vista integral del autor para proponer en este artículo una perspectiva diferente sobre la inducción de este tipo de estructuras. Debido a la extraordinaria diversidad de formas, colores y estructuras complejas presentes en las agallas de insectos, las mismas constituyen modelos útiles para estudiar cómo la forma y la estructura son determinadas a nivel molecular en los sistemas vegetales. Además, las agallas de plantas son un importante origen de material para el estudio y exploración de nuevas sustancias químicas de interés humano, debido a las características fisiológicas y adaptativas que presentan. Considerando el control fino del proceso de morfogénesis, regulación bioquímica y complejidad estructural de las agallas de insectos, se propone que un mecanismo de inducción mediado por la inserción de elementos genéticos exógenos dentro del genoma de las células de la planta que forman la agalla podría estar involucrado en la formación de este tipo de estructuras, vía una bacteria endosimbiótica.

Palabras clave: agallas de insectos, insecto inductor, mecanismo de inducción, morfogénesis vegetal, efectores.

\section{REFERENCES}

Abrahamson, W. G., \& Weis, A. (1997). Evolutionary ecology across three trophic levels: goldenrods, gallmakers, and natural enemies. Princeton University: New Jersey, USA.

Álvarez, R., Molist, P., González-Sierra, S., Martínez, J. J., \& Nieto-Nafría, J. (2014). The histo structure of galls induced by aphids as a useful taxonomic character: the case of Rectinasus (Hemiptera, Aphididae, Eriosomatinae). Zootaxa, 5(3861), 487-492. DOI: 10.11646/zootaxa.3861.5.6

Ananthakrishnan, T. (1998). Insect gall systems: Patterns, processes and adaptive diversity. Current Science, 75(7), 672-676. Retrieved from http://www.jstor.org/ stable/24101708

Agudelo, I., Cogoi, L., Filip, R., Kuzmanich, N., Wagner, M. L., \& Ricco, R. A. (2018). Anatomy, histochemistry, and comparative analysis of hydroxycinnamic 
derivatives in healthy leaves and galls induced by Baccharopelma spp. (Hemiptera: Psyllidae) in Baccharis spicata (Lam) Baill (Asteraceae). Biochemical Systematics and Ecology, 77, 22-30. DOI: 10.1016/j. bse.2018.01.001

Arduin, M., \& Kraus, J. E. (1995). Anatomia e ontogenia de galhas foliares de Piptadenia gonoacantha (Fabales, Mimosaceae). Boletim de Botânica da Universidade de São Paulo, 14, 109-130.

Bedetti, C. S., Ferreira, B. G., de Castro, N. M., \& dos Santos Isaias, R. M. (2013). The influence of parasitoidism on the anatomical and histochemical profiles of the host leaves in a galling Lepidoptera - Bauhinia ungulata system. Revista Brasileira de Biociências, 11(2), 242-249.

Bedetti, C. S, Modolo, L. V., \& dos Santos Isaias, R. M. (2014). The role of phenolics in the control of auxin in galls of Piptadenia gonoacantha (Mart.) $\mathrm{MacBr}$ (Fabaceae: Mimosoideae). Biochemical Systematics and Ecology, 55, 53-59. DOI:10.1016/j. bse.2014.02.016

Bailey, S., Percy, D. M., Hefer, C. A., \& Cronk, Q. C. B. (2015). The transcriptional landscape of insect galls: psyllid (Hemiptera) gall formation in Hawaiian Metrosideros polymorpha (Myrtaceae). BMC Genomics, 16(1), 943. DOI: 10.1186/s12864-015-2109-9

Barnewall, E. C. \& De Clerck-Floate, R. A. (2012). A preliminary histological investigation of gall induction in an unconventional galling system. ArthropodPlant Interactions, 6(3), 449-459. DOI: 10.1007/ s11829-012-9193-4

Braendle, C., Miura, T., Bickel, R., Shingleton, A., Kambhampati, S., \& Stern, D. (2009). Developmental Origin and Evolution of Bactariocytes in the AphidBuchnera Symbiosis. Plos Biology, 1(1), 70-76. DOI: 10.1371/journal.pbio.0000021

Bartlett, L., \& Connor, E. F. (2014). Exogenous phytohormones and the induction of plant galls by insects. Arthropod-Plant Interactions, 8(4), 339-348. DOI: 10.1007/s11829-014-9309-0

Boivin, T., Henri, H., Vavre, F., Gidoin, C., Veber, P., Candau, J. N., ... Auger-Rozenberg, M. A. (2014). Epidemiology of asexuality induced by the endosymbiotic Wolbachia across phytophagous wasp species: host plant specialization matters. Molecular Ecology, 23(9), 2362-2375. DOI: 10.1111/mec.12737

Boysen-Jensen, P. (1952). Untersuchungen über die Bildung der Galle von Mikiola fagi. Danske Videnskab. Selskab Biologiske Meddelelser, 18(18), 1-18.

Brentassi, M. U., Franco, E., Balatti, P., Medina, R., Bernabei, F., \& Remes Lenicov, A. M. (2017). Bacteriomes of the corn leafhopper, Dalbulus maidis (DeLong \& Wolcott, 1923) (Insecta, Hemiptera, Cicadellidae: Deltocephalinae) harbor Sulcia symbiont: molecular characterization, ultrastructure, and transovarial transmission. Protoplasma, 254(3), 1421-1429. DOI: 10.1007/s00709-016-1033-4

Brütting, C., Crava, C. M., Schäfer, M., Schuman, M. C., Meldau, S., Adam, N., \& Baldwin, I. T. (2018). Cytokinin transfer by a free-living mirid to Nicotiana attenuata recapitulates a strategy of endophytic insects. eLife, 7, e36268. DOI: 10.7554/eLife.36268

Chrostek, E. \& Teixeira, L. (2015). Mutualism Breakdown by Amplification of Wolbachia Genes. PLoS Biology, 13(2), e1002065. DOI: 10.1371/journal. pbio. 1002065

Campbell, M. A., Van Leuven, J. T., Meister, R. C., Carey, K. M., Simon, C., \& McCutcheon, J. P. (2015). Genome expansion via lineage splitting and genome reduction in the cicada endosymbiont Hodgkinia. Proceedings of the National Academy of Sciences of the United States of America, 112(33), 10192-10199. DOI: $10.1073 /$ pnas. 1421386112

Casper-Lindley, C., Kimura, S., Saxton, D. S., Essaw, Y., Simpson, I., Tan, V., \& Sullivan, W. (2011). Rapid fluorescence-based screening for Wolbachia endosymbionts in Drosophila germ line and somatic tissues. Applied and Environmental Microbiology, 77(14), 4788-4794. DOI: 10.1128/AEM.00215-11

Carneiro, R. G., \& Isaias, R. M. S. (2015). Gradients of metabolic accumulation and redifferentiation of nutritive cells associated with vascular tissues in galls induced by sucking-insects. AOB Plants, 7, plv086. DOI: $10.1093 /$ aobpla/plv086

Chen, H., Liu, J., Cui, K., Lu, Q., Wang, C., Wu, H., ... Ling, X. (2018). Molecular mechanisms of tannin accumulation in Rhus galls and genes involved in plant-insect interactions. Scientific Reports, 8(1), 9841. DOI: 10.1038/s41598-018-28153-y

Coelho, M. S., Almada, E. D., Fernandes, G. W., Carneiro, M. A., Dos Santos, R. M., Quintino, A. V., \& Sanchez-Azofeifa, A. (2009). Gall inducing arthropos from a seasonally dry tropical forest in Serrá do Cipó, Brazil. Revista Brasileira de Entomologia, 53(3), 404-414. DOI: 10.1590/S0085-56262009000300015

Connor, E. F., Bartlett, L., O’Toole, S., Byrd, S., Biskar, K., \& Orozco, J. (2012). The mechanism of gall induction makes galls red. Arthropod-Plant Interactions, 6(4), 489-495. DOI: $10.1007 / \mathrm{s} 11829-012-9210-7$

Cornell, H. V. (1983). The secondary chemistry and complex morphology of galls formed by the Cynipinae. Why and how? American Midland Naturalist, 110(2), 225-234. DOI: $10.2307 / 2425263$

Cotrim Costa, E., Gonçalves da Silva Carneiro, R., Santos Silva, J., \& Isaias, R. (2018). Biology and development of galls induced by Lopesia sp. (Diptera: Cecidomyiidae) on leaves of Mimosa gemmulata 
(Leguminosae: Caesalpinioideae). Australian Journal of Botany, 66(2), 161-172. DOI: 10.1071/BT17099

Dalbem, R. V., \& Mendonça, M. (2006). Diversity of galling Artropods and Host Plants in a Subtropical Forest of Porto Alegre, Southern Brazil. Neotropical Entomology, 35(5), 616-624. DOI: 10.1590/ S1519-566X2006000500007

Davey, M. R., Curtis, I., Gartland, K., \& Power J. B. (1994). Agrobacterium-Induced crown gall and hairy rots deseases: their biology and aplication to plant genetics engineering. In M. Williams (Ed.), Plant Galls: Organisms, Interactions, Populations. The Systematics Association (Special Vol. 49, pp. 283299). London, United Kingdom: Clarendon Press.

Degnan, P., Lazarus, A. B., \& Wernegreen, J. J. (2005). Genome sequence of Blochmannia pennsylvanicus indicates parallel evolutionary trends among bacterial mutualists of insects. Genome Research, 15(8), 10231033. DOI: $10.1101 /$ gr.3771305

De la Cruz, F., \& Davies, J. (2000). Horizontal gene transfer and the origin of species: lessons from bacteria. Trends in Microbiolgy, 8(3), 128-133. DOI: 10.1016/ S0966-842X(00)01703-0

Delmotte, F., Rispe, C., Schaber, J., Silva, F. J., \& Moya, A. (2006). Tempo and mode of early gene loss in endosymbiotic bacteria from insects. BMC Evolutionary Biology, 6(1), 56. DOI: 10.1186/1471-2148-6-56

Diao, X., Freeling, M., \& Lisch, D. (2006). Horizontal Transfer of a Plant Transposon. Plos Biology, 4(1), 119-128. DOI: 10.1371/journal.pbio.0040005

El-Sayed, W. S., \& Ibrahim, R. A. (2015). Diversity and phylogenetic analysis of endosymbiotic bacteria of the date palm root borer Oryctes agamemnon (Coleoptera: Scarabaeidae). BMC Microbiology, 15(1), 88. DOI: 10.1186/s12866-015-0422-8

Erb, M., Meldau, S., \& Howe, G. A. (2012). Role of phytohormones in insect-specific plant reactions. Trends in Plant Sciences 17(5), 250-259. DOI: 10.1016/j. tplants.2012.01.003

Espírito-Santo, M. M., \& Fernandes, G. W. (2007). How Many Species of Gall-Inducing Insects Are There on Earth, and Where Are They? Annals of the Entomological Society of America, 100(2), 95-99. DOI: $10.1603 / 0013-8746(2007) 100[95: H M S O G I] 2$ $.0 . \mathrm{CO} ; 2$

Espírito-Santo, M., Neves, F., Andrade-Neto, F. R., \& Fernandes, G. (2007). Plant architecture and meristem dynamics as the mechanisms determining the diversity of gall-inducing insects. Oecologia, 153(2), 353-64. DOI: 10.1007/s00442-007-0737-8

Fagan, M. (1918). The Uses of Insect Galls. The American Naturalist, 52(614), 155-176. Retrieved from http:// www.jstor.org/stable/2456142
Ferreira, B. G., \& Isaias, R. M. S. (2013). Developmental stem anatomy and tissue redifferentiation induced by a galling Lepidoptera on Marcetia taxifolia (Melastomataceae). Botany, 91(11), 752-760. DOI: 10.1139/ cjb-2013-0125

Ferreira, B. G., Álvarez, R., Avritzer, S. C., \& Isaias, R. M. S. (2017). Revisiting the histological patterns of storage tissues: beyond the limits of gall-inducing taxa. Botany, 95(2), 173-184. DOI: 10.1139/cjb-2016-0189

Formiga, A. T., Silveira, F. A., Fernandes, G. W., \& Isaias, R. M. (2015). Phenotypic plasticity and similarity among gall morphotypes on a superhost, Baccharis reticularia (Asteraceae). Plant Biology, 17(2), 512521. DOI: $10.1111 / \mathrm{plb} .12232$

Fukatsu, T., Koga, R., Smith, W. A., Tanaka, K., Nikoh, N., Sasaki-Fukatsu, K., ... \& Clayton, D. H. (2007). Bacterial Endosymbiont of the Slender Pigeon Louse Columbicola columbae, Allied to Endosymbionts of Grain Weevils and Tsetse Flies. Applied and Environmental Microbiology, 73(20), 6660-6668. DOI: 10.1128/AEM.01131-07

Ghosh, S., Bouvaine, S., \& Maruthi, M. (2015). Prevalence and genetic diversity of endosymbiotic bacteria infecting cassava whiteflies in Africa. BMC Microbiology, 15(1), 93. DOI: 10.1186/s12866-015-0425-5

Giron, D., \& Huguet, E. (2011). A genomically tractable and ecologically relevant model herbivore for a model plant: new insights into mechanisms of insect- plant interactions and evolution. Molecular Ecology, 20(5), 990-994. DOI: 10.1111/j.1365-294X.2010.04902.x

Giron, D., Frago, E., Glevarec, G., Pieterse, C. M. J., \& Dicke, M. (2013). Cytokinins as key regulators in plant-microbe-insect interactions: Connecting plant growth and defence. Funtional Ecology, 27(3), 599609. DOI: $10.1111 / 1365-2435.12042$

Giron, D., \& Glevarec, G. (2014). Cytokinin-induced phenotypes in plant-insect interactions: learning from the bacterial world. Journal of Chemical Ecology, 40(7), 826-835. DOI: 10.1007/s10886-014-0466-5

Giron, D., Huguet, E., Stone, G. N., \& Body, M. (2016). Insect-induced effects on plants and possible effectors used by galling and leaf-mining insects to manipulate their host-plant. Journal of Insect Physiology, 84, 70-89. DOI: 10.1016/j.jinsphys.2015.12.009

Gómez, L. D., \& Kisimova-Horovitz, L. (1997). Basidiomycetes. Exobasidiales, Cryptobasidiales. Historic, taxonomic and phytogeographic notes. Revista de Biología Tropical, 45(4), 1293-1310.

Goodacre, S. L., \& Martin, O. Y. (2012). Modification of insect and arachnid behaviours by vertically transmitted endosymbionts: infections as drivers of behavioural change and evolutionary novelty. Insects, 3(1), 246-261. DOI: 10.3390/insects3010246 
Goto, S., Anbutsu, H., \& Fukutsa, T. (2006). Asymmetrical interactions between Wolbachia and Spiroplasma endosymbionts coexisting in the sema insect host. Applied and Environmental Microbiology, 72(7), 4805-4810. DOI: 10.1128/AEM.00416-06

Güçlü, S., Hayat, R., Shorthouse, J. D., \& Göksel, T. (2008). Gall-inducing wasp of the genus Diplolepis (Hymenoptera: Cynipidae) on Shrub Roses of Turkey. Proceedings of the Entomological Society of Washington, 110(1), 204-218. DOI: 10.4289/0013-8797-110.1.204

Guimarães, A. L., Neufeld, P. M., Santiago-Fernandes, L. D., \& Vieira, A. C. (2015). Structure and development of 'witches' broom' galls in reproductive organs of Byrsonima sericea (Malpighiaceae) and their effects on host plants. Plant Biology, 17(2), 493-504. DOI: $10.1111 /$ plb.12231

Gutzwiller, F., Dedeine, F., Káiser, W., \& Giron, D. (2015). Correlation between the green-island phenotype and Wolbachia infections during the evolutionary diversification of Gracillariidae leaf-mining moths. Ecology and Evolution, 5(18), 4049-4062. DOI: $10.1002 /$ ece 3.1580

Hall, C. R., Carroll, A. R., \& Kitching, R. L. (2017) A meta-analysis of the effects of galling insects on host plant secondary metabolites. ArthropodPlant Interactions, 11(4), 463-473. DOI: 10.1007/ s11829-016-9486-0

Hammer, T. J., \& Bowers, M. D. (2015). Gut microbes may facilitate insect herbivory of chemically defended plants. Oecologia, 179(1), 1-14. DOI: 10.1007/ s00442-015-3327-1

Hansen, A. K., \& Moran, N. A. (2014). The impact of microbial symbionts on host plant utilization by herbivorous insects. Molecular Ecology, 23(6), 14731496. DOI: $10.1111 / \mathrm{mec} .12421$

Hanson, P. E., \& Gómez-Laurito, J. (2005). Diversity of Gall-inducing Arthropods of Costa Rica. In A. Raman, C. W. Schaefer, \& T. M. Withers (Eds.), (2005). Biology, ecology, and evolution of gallinducing arthropods (Vol. 1, pp. 673-692). New Hampshire, USA: Science Publishers.

Hernández-Soto, P., Lara-Flores, M., Agredano-Moreno, L., Jiménez-García, L., Cuevas-Reyes, P., \& Oyama, K. (2015). Developmental morphology of bud galls induced on the vegetative meristems of Quercus castanea by Amphibolips michoacaensis (Hymenoptera: Cynipidae). Botanical Sciences, 93(4), 685-693. DOI: 10.17129/botsci.607

Hartnett, D., \& Abrahamson, W. (1979). The effects of stem gall insects on life history patterns in Solidago canadensis. Ecology, 60(5), 910-917. DOI: $10.2307 / 1936859$

Hearn, J. (2013). Exploring population history and gall induction in cynipid gall wasps using genomics and transcriptomics (Doctoral dissertation). University of Edinburgh, Scotland, United Kingdom.

Hentschel, U., Steinert, M., \& Hacker, J. (2000). Common molecular mechanism of symbiosis and pathogenesis. Trends in Microbiology, 8(5), 226-231. DOI: $10.2307 / 1936859$

Herren, J. K., Paredes, J. C., Schüpfer, F., \& Lemaitre, B. (2013). Vertical Transmission of a Drosophila Endosymbiont via Cooption of the Yolk Transport and Internalization Machinery. mBio, 4(2), e0053212. DOI: $10.1128 / \mathrm{mBio} .00532-12$

Ho, M. S., Tsai, P. I., \& Chien, C. T. (2006). F-box proteins: the key to protein degradation. Journal of Biomedical Science, 13(2), 181-191. DOI: 10.1007/ s11373-005-9058-2

Hori, K. (1992). Insect secretion and their effect on plant growth, with special reference to hemipterans. In J. D. Shorthouse \& O. Rohfritsch (Eds.), Biology of Insect-Induced Galls. New York, USA: Oxford University Press.

Hough, J. S. (1953). Studies on the Common Spangle Gall of Oak: II. A General Consideration of Past Work on Gall Induction. New Phytologist, 52(3), 218-228. DOI: $10.1111 /$ j.1469-8137.1953.tb07512.x

Huang, M. Y., Huang, W. D., Chou, H. M., Chen, C. C., Chen, P. J., Chang, Y. T., \& Yang, C. M. (2015). Structural, biochemical, and physiological characterization of photosynthesis in leaf-derived cup-shaped galls on Litsea acuminata. BMC Plant Biology, 15(1), 61. DOI: $10.1186 / \mathrm{s} 12870-015-0446-0$

Inbar, M., Izhaki, I., Koplovich, A., Lupo, I., Silanikove, N., Glasser, T., ... Lev-Yadun, S. (2010). Why do many galls have conspicuous colors? A new hypothesis. Arthropod-Plant Interactions, 4(1), 1-6.

Isaias, R. M. S., Oliveira, D. C., Moreira, A. S. F. P., Soares, G. L. G., \& Carneiro, R. G. S. (2015). The imbalance of redox homeostasis in arthropod-induced plant galls: Mechanisms of stress generation and dissipation. Biochimica et Biophysica Acta (BBA)-General Subjects, 1850(8), 1509-1517. DOI: 10.1016/j. bbagen.2015.03.007

Isaias, R. M. S., Ferreira, B. G., Alvarenga, D. R., Barbosa, L. R., Salminen, J. P., \& Steinbauer, M. J. (2018). Functional compartmentalisation of nutrients and phenolics in the tissues of galls induced by Leptocybe invasa (Hymenoptera: Eulophidae) on Eucalyptus camaldulensis (Myrtaceae). Austral Entomology, 57(2), 238-246. DOI: 10.1111/aen.12336

Ishii, Y., Matsuura, Y., Kakizawa, S., Nikoh, N., \& Fukatsu, T. (2013). Diversity of bacterial endosymbionts associated with macrosteles leafhoppers vectoring phytopathogenic phytoplasmas. Applied and Environmental Microbiology, 79(16), 5013-5022. DOI: 10.1128/AEM.01527-13 
Jaenike, J., Polak, M., Fiskin, A., Helou, M., \& Minhas, M. (2007). Interspecific transmission of endosymbiotic Spiroplasma by mites. Biology Letters, 3(1), 23-25. DOI: $10.1098 /$ rsbl.2006.0577

Jayaprakashvel, M., Bharathi, C. D., Muthezhilan, R., \& Hussain, A. J. (2017). Horizontal transfer of heavy metal resistance plasmid from a brackish water bacterium Pseudomonas sp. AMET1221 to Escherichia coli DH5 $\alpha$. International Journal of Pure \& Applied Biosciences, 5(2), 1199-1206. DOI: 10.18782/2320-7051.2430

Kageyama, D., Narita, S., \& Watanabe, M. (2012). Insect Sex Determination Manipulated by Their Endosymbionts: Incidences, Mechanisms and Implications. Insects, 3(1), 161-199. DOI: 10.3390/insects3010161

Kaiser, W., Huguet, E., Casas, J., Commin, C., \& Giron, D. (2010). Plant green-island phenotype induced by leaf-miners is mediated by bacterial symbionts. Proceedings of the Royal Society B: Biological Sciences, 277(1692), 2311-2319. DOI: 10.1098/rspb.2010.0214

Klasson, L., Kambris, Z., Cook, P. E., Walker, T., \& Sinkins, S. P. (2009). Horizontal gene transfer between Wolbachia and the mosquito Aedes aegypti. BMC genomics, 10(1), 33, 1-9. DOI: 10.1186/1471-2164-10-3

Koga, R., Meng, X. Y., Tsuchida, T., \& Fukatsu, T. (2012). Cellular mechanism for selective vertical transmission of an obligate insect symbiont at the bacteriocyte-embryo interface. Proceedings of the National Academy of Sciences, 109(20), 1230-1237. DOI: $10.1073 /$ pnas.1119212109

Kot, I., Jakubczyk, A., Karaś, M., \& Złotek, U. (2017). Biochemical responses induced in galls of three Cynipidae species in oak trees. Bulletin of Entomological Research, 108(4), 494-500. DOI: 10.1017/ S0007485317001055

Kremer, N., Charif, D., Henri, H., Gavory, F., Wincker, P., \& Mavingui, P. (2012). Influence of Wolbachia on host gene expression in an obligatory symbiosis. BMC Microbiology, 12(1), 1-16. DOI: 10.1186/1471-2180-12-S1-S7

Kikuchi, Y., Meng, X. Y., \& Fukatsu, T. (2005). Gut Symbiotic bacteria of the genus Burkholderi in the Broad- Headed Bugs Riptortus clavatus and Leptocorisa chinensis (Heteroptora: Alydidae). Applied and Environmental Microbiology, 71 (7), 4035-4043. DOI: 10.1128/AEM.71.7.4035-4043.2005

Korotyaev, B. A., Konstantinov, A. S., Lingafelter, S. W., Mandelshtam, M. Y., \& Volkovitsh, M. G. (2005). Gall-inducing Coleoptera. Biology, ecology, and evolution of gall-inducing arthropods. In A. Raman, C. W. Schaefer, \& T. M. Withers (Eds.), Biology, ecology, and evolution of gall-inducing arthropods (239272). New Hampshire, USA: Science Publishers.
Kraus, C., \& Spiteller, G. (1997). Comparison of phenolic compound from galls and shoots of Picea glauca. Phytochemistry, 44(1), 59-67. DOI: 10.1016/ S0031-9422(96)00388-3

Krawczyk, K., Szymańczyk, M., \& Obrępalska-Stęplowska, A. (2015). Prevalence of endosymbionts in polish populations of Leptinotarsa decemlineata (Coleoptera: Chrysomelidae). Journal of Insect Science, 15(1), 106. DOI: $10.1093 /$ jisesa/iev085

Kondo, N., Shimada, M., \& Fukatsu, T. (2005). Infection density of Wolbachia endosymbiont affected by coinfection and host genotype. Biology Letters, 1(4), 488-491. DOI: $10.1098 /$ rsbl.2005.0340

Kyndt, T., Quispe, D., Zhai, H., Jarret, R., Ghislain, M., Liu, Q., ... Kreuze, J. F. (2015). The genome of cultivated sweet potato contains Agrobacterium T-DNAs with expressed genes: an example of a naturally transgenic food crop. Proceedings of the National Academy of Sciences, 112(18), 5844-5849. DOI: 10.1073/pnas.1419685112

Li, X. Q., Liu, Y. Z., Guo, W. F., Solanki, M. K., Yang, Z. D., Xiang, Y., ... Wen, Y. G. (2017). The gall wasp Leptocybe invasa (Hymenoptera: Eulophidae) stimulates different chemical and phytohormone responses in two Eucalyptus varieties that vary in susceptibility to galling. Tree Physiology, 37(9), 1208-1217. DOI: 10.1093/treephys/tpx098

Leitch, I. J. (1994). Induction and development of the bean gall caused by Pontania proxima. In M. Williams (Ed.), Plant Galls: Organisms, Interactions, Populations. The Systematics Association (Systematics Association Special Vol. 49, pp. 283-283). London, United Kingdom: Clarendon Press, Oxford.

Ma, W. J., Vavre, F., \& Beukeboom, L. W. (2014). Manipulation of arthropod sex determination by endosymbionts: diversity and molecular mechanisms. Sexual Development, 8(1-3), 59-73. DOI: $10.1159 / 000357024$

Ma, W. J., Pannebakker, B. A., van de Zande, L., Schwander, T., Wertheim, B., \& Beukeboom, L. W. (2015). Diploid males support a two-step mechanism of endosymbiont-induced thelytoky in a parasitoid wasp. BMC Evolutionary Biology, 15(1), 84. DOI: 10.1186/s12862-015-0370-9

Ma, W. J., \& Schwander, T. (2017). Patterns and mechanisms in instances of endosymbiont-induced parthenogenesis. Journal of Evolutionary Biology, 30(5), 868-888. DOI: 10.1111/jeb.13069

McCalla, D., Genthe, M., \& Hovanitz, W. (1961). Chemical Nature of an Insect Gall Growth-Factor. Plant Physiology, 37, 98-103. Retrieved from https://www. ncbi.nlm.nih.gov/pmc/articles/PMC549743

Maia, V. C., \& Oliveira, J. C. (2010). Galhas de insectos de Reserva Biólogica Estadual da Praia do Sul (Ilha 
Grande, Angra dos Reis, R.J). Biotaneotropica, 10(4), 227-238. Retrieved from http://www.biotaneotropica. org.br/v10n4/en/abstract?inventory+bn04110042010

Maia, V. C., Fernandes, G. W., Magalhãcs, H., \& Santos, J. C. (2010a). Two new species of Lopesia Rübsaamen (Diptera, Cecidomyiidae) associated with Mimosa hostiles (Mimosaceae) in Brazil. Revista Brasileira de Entomologia, 54(4), 578-583. DOI: 10.1590/ S0085-56262010000400007

Maia, V. C., Fleury, G., Soares, G. L. G., \& Isaias, R. M. S. (2010b). Description of the female, pupa and gall of Pisphondylia brasiliensis Couri and Maia, 1992 (Diptera: Cecidomyiidae, Schizomyiina) with new records. Brazilian Journal of Biology, 70(4), 10591063. DOI: 10.1590/S1519-69842010000500021

Maia, V. C. (2014). Insect Galls of Itamonte (Minas Gerais, Brazil): Characterization and occurrence. Biota Neotropica, 14(1), 1-17. DOI: 10.1590/S1676-06033839

Mapes, C. C., \& Davies, P. J. (2001). Indole-3-acetic acid and ball gall development on Solidago altissima. New Phytologist, 151(1), 195-202. DOI: 10.1046/j.1469-8137.2001.00161.x

Mariño, Y. A., Verle Rodrigues, J. C., \& Bayman, P. (2017). Wolbachia Affects Reproduction and Population Dynamics of the Coffee Berry Borer (Hypothenemus hampei): Implications for Biological Control. Insects, 8(1), 8. DOI: $10.3390 /$ insects 8010008

Mani, M. S. (1992). Introduction to Cecidology. In J. D. Shorthouse \& O. Rohfritsch (Eds.), Biology of InsectInduced Galls (pp. 1-7). New York, USA: Oxford University Press.

Martins dos Santos, I., Pereira Lima, V., Souza Suares, E. K., de Paula, M., \& Calado, D. C. (2018). Insect galls in three species of Copaifera L. (Leguminosae, Caesalpinioideae) occurring sympatrically in a Cerrado area (Bahia, Brazil). Biota Neotropica, 18(1), 1-5. DOI: $10.1590 / 1676-0611-B N-2017-0356$

Medianero, E., Paniagua, M., \& Castaño-Meneses, G. (2010). Comparación temporal de la riqueza y composición de insectos inductores de agallas en el dosel de un bosque tropical. Revista Mexicana de Biodiversidad, 81(2), 465-472. Retrieved from https://www. researchgate.net/publication/262634199

Medina, C., da Rocha, M., Magliano, M., Raptopoulo, A., Marteu, N., Lebrigand, K., ... Jaubert-Possamai, S. (2018). Characterization of siRNAs clusters in Arabidopsis thaliana galls induced by the root-knot nematode Meloidogyne incognita. BMC genomics, 19(1), 943. DOI: 10.1186/s12864-018-5296-3

Mellah, R., Enhassaïni, H. B., \& Álvarez, R. A. (2016) Histo-anatomy of Pistacia terebinthus L. leaflets galls induced by Paracletus cimiciformis von Heyden and Geö̈ca utricularia Passarini. Two aphids in western Algerian region. International Journal of
Geobotanical Research, 6, 1-8. DOI: 10.5616/ijgr 160001

Miles, P. W. (1968). Insect Secretions in Plants. Phytopathology, 6, 137-164. DOI: 10.1146/annurev. py.06.090168.001033

Mouton, L., Henri, H., Buoletreau, M., \& Vavre F. (2003). Strain-specific regulation of intracellular Wolbachia density in multiply infected insect. Molecular Ecology, 12(12), 3459-3465. DOI: 10.1046/j.1365-294X.2003.02015.x

Muñoz-Viveros, A. L., Martinez, J. J. I., Molist, P., González-Sierra, S., Julián, P. G., \& Álvarez, R. (2014). Microscopic study of galls induced by three species of Geopemphigus (Hemiptera: Aphididae: Eriosomatinae) on Pistacia mexicana. ArthropodPlant Interactions, 8(6), 531-538. DOI: 10.1007/ s11829-014-9333-0

Nabity, P. D., Haus, M. J., Berenbaum, M. R., \& Delucia, E. H. (2013). Leaf-galling Phylloxera on grapes reprograms host metabolism and morphology. Proceedings of the National Academy of Sciences, 110(41), 16663-16668. DOI: 10.1073/pnas. 1220219110

Naseem, M., Wölfling, M., \& Dandekar, T. (2014). Cytokinins for immunity beyond growth, galls, and green islands. Trends in Plant Science, 19(8), 481-484. DOI: $10.1016 /$ j.tplants.2014.04.001

Nikoh, N., \& Nakabachi, A. (2009). Aphids acquired symbiotic genes via lateral gene transfer. BMC Biology, 7(1), 12. DOI: $10.1186 / 1741-7007-7-12$

Nikoh, N., Tanaka, K., Shibata, F., Kondo, N., Hizume, M., Shimada, M., \& Fukatsu, T. (2008). Wolbachia genome integrated in an insect cromosome: Evolution and fate of laterally transferred endosymbiont genes. Genome research, 18(2), 272-280. DOI: 10.1101/ gr.7144908

Nogueira, R. M., Costa, E. C., Silva, J. S., \& Isaias, R. M. (2018). Structural and histochemical profile of Lopesia sp. Rübsaamen 1908 pinnula galls on Mimosa tenuiflora (Willd.) Poir. in a Caatinga environment. Hoehnea, 45(2), 314-322. DOI: 10.1590/2236-8906-80/2017

Nyman, T., \& Julkunen, R. (2000). Manipulation of the phenolic chemistry of willows by gall-inducing sawflies. Proceedings of the National Academy of Sciences, 97(24), 13184-13187. DOI: 10.1073/ pnas. 230294097

Oates, C. N., Külheim, C., Myburg, A. A., Slippers, B., \& Naidoo, S. (2015). The transcriptome and terpene profile of Eucalyptus grandis reveals mechanisms of defense against the insect pest, Leptocybe invasa. Plant Cell Physiology, 56(7), 1418-1428. DOI: $10.1093 / \mathrm{pcp} / \mathrm{pcv} 064$ 
Oates, C. N, Denby, K. J., Myburg, A. A., Slippers, B., $\&$ Naidoo, S. (2016). Insect Gallers and Their Plant Hosts: From Omics Data to Systems Biology. International Journal of Molecular Sciences, 17(11), 1891. DOI: $10.3390 / \mathrm{ijms} 17111891$

Oliveira, D. C., \& Isaias, R. M. S. (2010). Cytological and histochemical gradients induced by a sucking insect in galls of Aspidosperma australe Arg. Muell (Apocynaceae). Plant Science, 178(4), 350-358. DOI: 10.1016/j.plantsci.2010.02.002

Oliveira, D. C., Carneiro, R. G. S., Magalhães, T. A., \& Isaias, R. M. S. (2011). Cytological and histochemical gradients on two Copaifera langsdorffii Desf. (Fabaceae)-Cecidimyiidae gall systems. Protoplasma, 248(4), 829-837. DOI: 10.1007/s00709-010-0258-x

Oliveira, D. C., Isaias, R. M. S., Fernandes, G. W., Ferreira, B. G., Carneiro, R. G. S., \& Fuzaro, L. (2016). Manipulation of host plant cells and tissues by gall-inducing insects and adaptive strategies used by different feeding guilds. Journal of Insect Physiology, 84, 103-113. DOI: 10.1016/j.jinsphys.2015.11.012

Oliver, K. M., Moran, N. A., \& Hunter, M. S. (2006). Costs and benefits of a superinfection facultative symbionts in aphids. Proceedings of the Royal Society B: Biological Sciences, 273(1591), 1273-1280. DOI: 10.1098/ rspb.2005.3436

Olszak, M., Truman, W., Stefanowicz, K., Sliwinska, E., Ito, M., Walerowski, P. ... \& Malinowski, R. (2018). Transcriptional profiling identifies critical steps of cell cycle reprogramming necessary for Plasmodiophora brassicae-driven gall formation in Arabidopsis. The Plant Journal, 97(4), 715-729. DOI: 10.1111/ tpj.14156

Palomares-Rius, J. E., Escobar, C., Cabrera, J., Vovlas, A., \& Castillo, P. (2017). Anatomical Alterations in Plant Tissues Induced by Plant-Parasitic Nematodes. Frontiers in Plant Science, 8, 1987. DOI: 10.3389/ fpls.2017.01987

Pawłowski, T. A., Staszak, A. M., Karolewski, P., \& Giertych, M. J. (2017). Plant development reprogramming by cynipid gall wasp: proteomic analysis. Acta Physiologiae Plantarum, 39(5), 114. DOI: 10.1007/ s11738-017-2414-9

Pinkwart, W., Diettrich, B., \& Luckner, M. (1998). Uptake of cardenolides from phloem sap into crown galls of Digitalis lanata. Phytochemistry, 49(1), 71-77. DOI: 10.1016/s0031-9422(97)01010-8

Piñol, M., Palazón, J., Cusidó, R., \& Serrano, M. (1996). Effects of Ri T - DNA Agrobacterium rhizogenes on growth y Hyoscyamine production in Datura stramonium roots cultures. Botanica Acta, 109, 133- 138 DOI: $10.1111 / \mathrm{j} .1438-8677.1996 . t b 00553 . x$

Price, P. W., Waring, G. L., \& Fernández, G. W. (1986). Hypotheses on the adaptive nature of galls.
Proceedings of the Entomological Society of Washington, 88(2), 361-363.

Porse, A., Schou, T. S., Munck, C., Ellabaan, M. M. H., \& Sommer, M. O. A. (2018). Biochemical mechanisms determine the functional compatibility of heterologous genes. Nature Communications, 9(1), 522. DOI: 10.1038/s41467-018-02944-3

Raman, A., Schaefer, C. W., \& Withers, T. M. (2005). Galls and gall-inducing arthropods: an overview of their biology, ecology and evolution. In A. Raman, C. W. Schaefer \& T. M. Withers (Eds), Biology, ecology, and evolution of gall-inducing arthropods (pp. 1-33). Enfield, USA, Science Publishers.

Raman, A. (2007). Biogeographical implications in species richness, biological diversity, and evolution of gall-inducing insects of the Orient and the eastern Palearctic. Oriental Insects, 41(1), 9-25. DOI: 10.1080/00305316.2007.10417496

Raman, A., Cruz, Z. T., Muniappan, R., \& Reddy, G. V. P. (2007). Biology and host specificity of gall-inducing Acythopeus burkhartorum (Coleoptera: Curculionidae), a biological-control agent for the invasive weed Coccinia grandis (Cucurbitaceae) in Guam and Saipan. Tijdschrift voor Entomologie, 150, 181-191. Retrieved from: http://www.nev.nl/tve

Raman, A. (2011). Morphogenesis of insect-induced plant galls: fact and questions. Flora-Morphology, Distribution, Functional Ecology of Plants, 206(6), 517533. DOI: 10.1016/j.flora.2010.08.004

Rankin, D. J., Rocha, E. P., \& Brown, S. P. (2011). What traits are carried on mobile genetic elements, and why? Heredity, 106(1), 1-10. DOI: 10.1038/ hdy. 2010.24

Rawat, N., Neeraja, C. N., Nair, S., \& Bentur, J. S. (2012). Differential gene expression in gall midge susceptible rice genotypes revealed by suppressive subtraction hybridization ( $\mathrm{SSH})$ cDNA libraries and microarray analysis. Rice, 5(1). Retrieved from http://www.thericejournal.com/content $/ 5 / 1 / 8$

Richardson, R. A., Body, M., Warmund, M. R., Schultz, J. C., \& Appel, H. M. (2016). Morphometric analysis of young petiole galls on the narrow-leaf cottonwood, Populus angustifolia, by the sugarbeet root aphid, Pemphigus betae. Protoplasma, 254(1), 203-216.

Rohfritsch, O., \& Shorthouse, J. D. (1982). Insect Galls. In G. Kahl \& J. S. Schell (Eds.), Molecular Biology of Plant Tumors (pp. 131-152). Academic Press: New York, USA.

Ronquist, F., \& Liljeblad, J. (2001). Evolution of gall wasphost plant association. Evolution, 55(12), 2501-2522.

Russell, J. A., Latorre, A., Sabater-Muñoz, B., Moya, A., \& Moran, N. A. (2003). Side-stepping secondary symbionts: widespred horizontal 
transfer across and beyong the Aphidoidea. Molecular Ecology, 12(4), 1061-1075. DOI: https:// doi.org/10.1046/j.1365-294X.2003.01780. $\mathrm{x} 10.1046 / \mathrm{j} .1365-294 X .2003 .01780 . \mathrm{x}$

Sá, C. E. M. D., Silveira, F. A., Santos, J. C., Isaias, R. M. D. S., \& Fernandes, G. W. (2009). Anatomical and developmental aspects of leaf galls induced by Schizomyia macrocapillata Maia (Diptera: Cecidomyiidae) on Bauhinia brevipes Vogel (Fabaceae). Brazilian Journal of Botany, 32(2), 319-327. DOI: $10.1590 / \mathrm{S} 0100-84042009000200011$

Saltzmann, K. D., Giovanini, M. P., Zheng, C., \& Williams, C. E. (2008). Virulent hessian fly larvae manipulate the free amino acid content of host wheat plants. Journal of Chemical Ecology, 34(11), 1401-1410. DOI: $10.1007 / \mathrm{s} 10886-008-9544-\mathrm{x}$

Sano, M., Havill, N. P., \& Ozaki, K. (2011). Taxonomic identity of a galling adelgid (Hemiptera: Adelgidae) from three spruce species in Central Japan. Entomological Science, 14(1), 94-99. DOI: https://doi. org/10.1111

Santos, J. C., Almeida-Cortez, J. S., \& Fernandes, G. W. (2011). Diversity of gall- inducing insects in the high altitude wetland forests in Pernambuco, Northeastern Brazil. Brazilian Journal of Biology, 71(1), 47-56. DOI: 10.1590/S1519-69842011000100008

Santos de Araújo, W. (2017). Plant species richness mediates the effects of vegetation structure, but not soil fertility, on insect gall richness in a savanna in Brazil. Journal of Tropical Ecology, 33(3), 197-204. DOI: $10.1017 / \mathrm{S} 0266467417000086$

Shih, T. H., Lin, S. H., Huang, M. Y., Sun, C. W., \& Yang, C. M. (2018). Transcriptome profile of cup-shaped galls in Litsea acuminata leaves. PloS One, 13(10), e0205265. DOI: 10.1371/journal.pone.0205265

Sinnott, E. W. (1960). Plant Morphogenesis. McGraw-Hill: New York, USA.

Shorthouse, J. D., \& Rohfritsch, O. (1992). Biology of the Insect-Induced Galls. Oxford University Press: New York, USA.

Silvia, M. S., \& Connor, E. F. (2017). Differences in meristems between monocots and dicots and susceptibility to attack by gall-inducing insects. ArthropodPlant Interactions, 11(4), 485-494. DOI: 10.1007/ s11829-017-9502-z

Spíchal, L. (2012). Cytokinins-Recent news and views of evolutionally old molecules. Functional Plant Biology, 39(4), 267-284. DOI: 10.1071/FP11276

Stone, G., \& Schönrogge, K. (2003). The adaptive significance of insect gall morphology. Trends in Ecology \& Evolution, 18(10), 512-522. DOI: 10.1016/ S0169-5347(03)00247-7
Stone, G., \& Cook, J. (1998). The structure of Cynipid oak galls: patterns in the evolution of an extended phenotype. Proceedings of the Royal Society of London. Series B: Biological Sciences, 265(1400), 979-988. DOI: $10.1098 / \mathrm{rspb} .1998 .0387$

Sugio, A., Dubreuil, G., Giron, D., \& Simon, G. C. (2015). Plant-insect interactions under bacterial influence: ecological implications and underlying mechanisms. Journal of Experimental Botany, 66(2), 467-478. DOI: $10.1093 / \mathrm{jxb} / \mathrm{eru} 435$

Suzuki, K., Moriguchi, K., \& Yamamoto, S. (2015). Horizontal DNA transfer from bacteria to eukaryotes and a lesson from experimental transfers. Research in Microbiology, 166(10), 753-763. DOI: 10.1016/j. resmic.2015.08.001

Thao, M. L., Gullan, P. L., \& Baumann, P. (2002). Secundary (gamma-Proteobacteria) endosymbionts infec the primary (beta- Proteobacteria) endosymbionts of mealybugs multiple times and coevolve with their hosts. Applied and Environmental Microbiology, 68(7), 3190-3197. DOI: 10.1128/ AEM.68.7.3190-3197.2002

Thao, M. L., Clark, M. A., Baumann, L., Brenan, E. B., Moran, N. A., \& Baumann, P. (2000). Secundary endosymbionts of psillyds have been acquired multiple times. Current Microbiology, 41(4), 300-304. DOI: $10.1007 / \mathrm{s} 002840010138$.

Toft, C., Williams, T. A., \& Fares, A. (2009). GenomeWide Funcional Divergence after Symbiosis of Protobacteria with Insect Unraveled through a Novel Computational Approach. PLoS Computational Biology, 5(4), 1-10. DOI: 10.1371/journal.pcbi.1000344

Tooker, J. F., \& De Moraes, C. M. (2008). Gall insect and indirect plant defenses. Plant Signaling and Behavior, 3(7), 503-504. DOI: 10.1111/j.1469-8137.2008.02392.x

Tooker, J. F., Rohr, J. R., Abrahamson, W. G., \& De Moraes, C. M. (2008). Gall insects can avoid and alter indirect plant defenses. New Phytologist, 178(3), 657-671. DOI: 10.1111/j.1469-8137.2008.02392.x

Tooker, J. F., \& Helms, A. M. (2014). Phytohormone Dynamics Associated with Gall Insects, and their Potential Role in the Evolution of the Gall-Inducing Habit. Journal of Chemical Ecology, 40(7), 742-753. DOI: 10.1007/s10886-014-0457-6

Valentine, L. (2003). Agrobacterium tumefaciens and the Plant: The David and Goliath of Modern Genetics. Plant Physiology, 133(3), 948-955. Retrieved from http://www.plantphysiol.org/cgi/doi/10.1104/ pp.103.032243.

Vereecke, D., Messens, E., Klarskov, K., Debruyn, A., Vanmontagu, M., \& Goethals, K. (1997). Patterns of phenolic compound in leafy galls of tobacco. Planta, 201(3), 342-348. 
Vecchi, C., Menezes, N. L., Oliveira, D. C., Ferreira, B. G., \& Isaias, R. M. S. (2013). The redifferentiation of nutritive cells in galls induced by Lepidoptera on Tibouchina pulchra (Cham.) Cogn. reveals predefined patterns of plant development. Protoplasma, 250(6), 1363-1368. DOI: 10.1007/s00709-013-0519-6.

Vivian, A., Murillo, J., \& Jackson, R. W. (2001). The role of plasmids in phytopathogenic bacteria: mobile arsenal? Microbiology, 147(4), 763-780. DOI: $10.1099 / 00221287-147-4-763$

von Wintersdorff, C. J., Penders, J., van Niekerk, J. M., Mills, N. D., Majumder, S., van Alphen, L. B., .. Wolffs, P. F. (2016). Dissemination of antimicrobial resistance in microbial ecosystems through horizontal gene transfer. Frontiers in Microbiology, 7, 173. DOI: 10.3389/fmicb.2016.00173

Weeks, A. R., Velten, R., \& Stouthamer, R. (2003). Incidence of a new sex-ratio distorting endosymbiotic bacterium among arthropods. Proceedings of the Royal Society of London. Series B: Biological Sciences, 270(1526), 1857-1865. DOI: 10.1098/ rspb.2003.2425.

Weis, A. E., Waltonand, C., Crego, L. (1988). Reactive plant tissue sites and the population biology of gall makers. Annual Review of Entomology, 33(1), 467-486.

Wielkopolan, B., \& Obrępalska-Stęplowska, A. (2016). Three-way interaction among plants, bacteria, and coleopteran insects. Planta, 244(2), 313-332. DOI: $10.1007 / \mathrm{s} 00425-016-2543-1$

Williams, M. (1994). Plant galls: a perpective. In M. Williams (Ed.), Plant Galls: Organisms, Interactions, Populations, The Systematics Association (Special
Volume No. 49, pp. 283-299). London, United Kingdom: Clarendon Press.

Wu, M., Sun, L. V., Vamathevan, J., Riegler, M., Deboy, R., Brownlie, J. C., ... Wiegand, C. (2004). Phylogenomics of the reproductive parasite Wolbachia pipientis wMel: a streamlined genome overrun by mobile genetic elements. PLoS Biology, 2(3), e69. DOI: 10.1371/journal.pbio.0020069

Xi, Z., Gavotte, L., Xie, Y., \& Dobson, S. (2008). Genome- wide analysis of the interaction between the endosimbiontic bacterium Wolbachia and its Drosophila hotss. BMC Genomics, 9(1), 1-12. DOI: 10.1186/1471-2164-9-1

Yamaguchi, H., Tanaka, H., Hasegawa, M., Tokuda, M., Asami, T., \& Suzuki, Y. (2012) Phytohormones and willow galls induction by a gall-inducing sawfly. New Phytologist, 196(2), 586-595. DOI: 10.1111/j.1469-8137.2012.04264.x

Yeo, U., Chae, Y., So, S., Lee, W., \& Sakurai, N. (1997). Developmental changes of sugar contents in the gall on the leaf of elm (Zelkowa serrato Makino) formed by Paracolopha morrisoni Baker (Homoptera). Journal of Plant Biology, 40(1), 67-71.

Zchori-Fein, E., \& Perlman, S. J. (2004). Distribution of the bacterial symbiont Cardinium in arthropods. Molecular Ecology, 13(7), 2009-2016. DOI: 10.1111/j.1365-294X.2004.02203.x

Zhao, C., Escalante, L. N., Chen, H., Benatti, T. R., Qu, J., Chellapilla, S., ... \& Batterton, M. (2015). A massive expansion of effector genes underlies gallformation in the wheat pest Mayetiola destructor. Current Biology, 25(5), 613-620. DOI: 10.1016/j. cub.2014.12.057 